IRA-International Journal of Management \& Social Sciences

ISSN 2455-2267; Vol.06, Issue 02 (2017)

Pg. no. 188-234

Institute of Research Advances

http://research-advances.org/index.php/RAJMSS

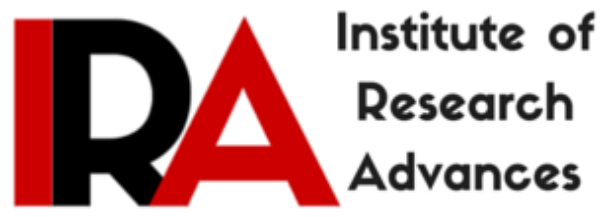

\title{
Assessing Factors Affecting Revenue Management in Public Sector: The Case of Halaba Special Woreda Town Administration Ethiopia (SNNPR)
}

\section{Dr. Pankaj Tiwari}

Assistant Professor, DPM, IPMDS, ECSU, Ethiopia.

Type of Review: Peer Reviewed.

DOI: http://dx.doi.org/10.21013/jmss.v6.n2.p6

\section{How to cite this paper:}

Tiwari, P. (2017). Assessing Factors Affecting Revenue Management in Public Sector: The Case of Halaba Special Woreda Town Administration Ethiopia (SNNPR). IRA-International Journal of Management \& Social Sciences (ISSN 2455-2267), 6(2), 188-234. doi:http://dx.doi.org/10.21013/jmss.v6.n2.p6

(C) Institute of Research Advances

(c)) EY-NC

This work is licensed under a Creative Commons Attribution-Non Commercial 4.0 International License subject to proper citation to the publication source of the work.

Disclaimer: The scholarly papers as reviewed and published by the Institute of Research Advances (IRA) are the views and opinions of their respective authors and are not the views or opinions of the IRA. The IRA disclaims of any harm or loss caused due to the published content to any party. 


\section{ABSTRACT}

Revenue management plays a great role for achieving the national objective of any nation which enhances the economic development and social wellbeing of the society. Even though revenue management has paramount importance for achieving the national goal of any nation, developing countries revenue management including, Ethiopia, is affected by a number of factors. The empirical findings of this research indicates that there are a number of factors that affect revenue management such as, Lack of awareness of tax payers, in adequate assessment of taxable sources, lack of clear operational procedures and so on, this research, thus intended to assess factors affecting public sector revenue management in Halaba special woreda Town administration (SNNPR). The specific objectives of the study are to identify the major factor that affect revenue collection, factors taken into consideration for revenue planning and to know the extent of revenue management mechanism help in revenue management of Halaba special woreda Town administration. Based on that fact, different literatures concerning the issue were reviewed to achieve these objectives; descriptive research method and stratified sampling were employed to gather data. Primary data were collected using semi structured questionnaires, interviews, focus group discussion and observations. Respondents who have participated in the study were employees (366) a sample of 88 were randomly selected from the Town administration of Halaba special woreda and taxpayers (151) a sample of 67 are randomly selected who have registered in the Inland revenue office, the study employed the Inland revenue management committee members (7) for focus group discussion and 4 from 6 Mayor Committee members for interview purposively selected. The total population of the study was 500 and the total sample size was 166. According to the response of the respondents, the factors that affected revenue management of Halaba special woreda Town administration are poor implementation, poor planning, inadequate assessment of taxable sources, lack of required skill, attitudinal problems of revenue officers, inaccurate information of taxpayers, lack of full automation and lack of awareness of taxpayers. Finally, based on the findings, possible recommendations are suggested, these include, widening the town's revenue sources base, improving planning and implementing capacity, establishing adequate data base systems, raising continuous awareness for taxpayers, institutionalizing standard accounting system that produces timely and reliable information, encouraging community participation in planning and revenue collection and need for designing the reward system.

Key words: Revenue Management, Revenue Collection, Planning.

\section{CHAPTER ONE}

\subsection{Introduction}

Revenue management plays a great role for achieving the national objective of any nation which enhances the economic development and social wellbeing of the society (Yusuf, 2012). Revenue management assists the scarce resources of a country to be spent in efficient and effective manner, by enabling the wise utilization of both the available and the forecasted revenue so that exhaustive extraction and proper utilization of the revenue potential will be ensured. Furthermore, revenue management involves all the procedures necessary for the government department for proper planning and fully executing the plan so that the Received cash is safely guarded and banked promptly. However, most of African countries face a lot of obstacles in either utilizing the available revenues in efficient and effective manner or exhaustively extracting the revenue potential (MOFED, 2009). An overview of budgeting suggests that all countries, either developed or developing, have come to grips with a constant struggle to face overwhelming demands for services while facing equally severe fiscal constraints (Francis et al, 2006).

Ethiopia is one among many countries which faces similar challenge. Currently, it follows a decentralized revenue management system, where the federal government and respective state constitutions stimulate revenue raising responsibilities of the different layers of government. Most regional states, however, do 
not cover their budget requirements from their own source of revenue. As a result, it is through the Federal Block Grant Transfers that each regional state covers its major proportion of their budget. The South Nations, Nationalities and People's Regional State (SNNPRS), is one of the 9 states which gets block grant to cover its budget deficits (MOFED, 2009).

On the other hand, as one of the 9 regional states, it has the full autonomy as per the FDRE constitution of 1995 which allows it to enact and execute its own state constitution and ratify laws as long as they comply with the federal constitution (1995 FDRE constitution, article 52). In contrast, the local authorities do not possess such a strong autonomy, due to the fact that they are not entitled to exercise such revenue autonomy as they don't have their own constitutional status.

However, since 2000, regional states have separated urban administration from the woredas and the former began to exercise a special statue. The new urban local governments (ULG) are supposed to represent a new decentralized unit of government with elected councils and having their own local tax revenues and expenditure responsibilities (Werner and Nguyen, 2007).

In Ethiopia, budgets are prepared at the federal level, consequently, regional states, woreda and urban administration levels depending on federal governments' policies and priorities, such as the expansion of health services to citizens, creating access to potable water, construction of roads and education have to align their budget demands and use.

Halaba special woreda is one of the 8 special woredas found in the South Nations Nationalities and Peoples Regional state, which was established in 1993 with different level of local government units. It prepares its budget from the regional state's block grant and revenue collected from rural land use and the revenue collected from different telethon programs to implement the development programs designed by the woreda government.

The special woreda town administration is one of the town administrations which were established in 1996 with its own elected councils, its own local tax revenues and expenditure management. Since its establishment, the town administration finances its own development programs from the revenue collected by town administration and block grant allocated by the regional state government. The woreda also produces a number of cash crop products which makes it the place where high transaction takes place. As a result of this high transaction, the woreda serves as a center for other woredas. The type of transaction includes jebena coffee services which is sold in the streets to large hotel investments. Moreover, in a week, three days of cattle market and the whole week of crop transaction take place especially on every Thursday.

Taking into consideration the above transactions revenue potentials through value added tax (VAT), turn over tax (TOT), user charges, land lease, fees and income taxes, the regional government urges the town administration to define or determine the amount of money it is expected to collect and also releases the amount of block grant allocated to the town administration to cover its spending. Hence, the budget for Halaba town administration is both the block grant allocated from the regional state and the revenue collected by the town administration. Even though the grant is properly funded by regional government, the town administration frequently faces a budget deficit (town administration report 2002-2006). As a result, it failed to cover part of its spending For the last three consecutive years (annual report of 2005 and 2006) and from my personal experience as a member of the federal parliament, I have the responsibility given by the Federal Democratic Republic of Ethiopian House of Peoples Representatives working procedure and members code of conduct Article $62 / 2005$ about the time to meet with the people who represented me(electorate) and discuss with different levels of government bodies and people on different social, economic and political affairs and report to the concerned body. One of the essential issues raised by my constituencies was regarding revenue management of the Halaba special Woreda town administration. The problem still exists and not yet solved. If this problem is not solved, it contradicts with Growth and Transformation Plan regarding macro-economic frame work which insists on boosting domestic revenue sources and to minimize dependence on loan and aid which have no guarantee 
and also set their own pre-conditions (GTP Document, 2003-2007).As is known, the more countries rely on such foreign budget source the more their sovereignty is in danger. This study, therefore, attempts to assess factors affecting revenue management in Halaba special woreda town administration and to suggest possible policy solutions based on the findings.

\subsection{Statement of the Problem}

The demand for public service and facilities increasing in terms of quality and quantity as the changing situations of the socio economic characteristics of the community from time to time. Hence, for satisfying this increasing public demand, public sector revenue management is vital for all countries in general, developing countries in particular. Public sector revenue management is as managing government revenue in public sectors. It is very important especially for developing countries because in developing countries there are many conditions in which market fails which become an obstacle for the nation's development. This market failure occurs when private sectors cannot address the issue because of a huge resource requirement and non-profitable nature of the sectors. In addition, Private sectors have no economic power to sustaining them because of huge resource requirement of the sectors. Moreover, they may not have interest to participate in non-profitable sectors and there are also some services which become quite risky for the public if they belonged to the private sectors (Scutaru, 2009). Thus, the government is responsible to correct the market failure in order to create a Conducive environment for the nation's development by addressing market failure. These in turn require huge resources that can be compensated by exhaustive exploitation of the revenue sources and wisely utilizing it for the intended purpose. Even though this is the case, developing countries are inefficient and ineffective in managing their revenues. As a result, they face huge budget deficit and rely on foreign loan and aid to cover the gap (Yousuf, 2012).

Local governments heavily rely on property taxes, which have proven to be relatively un responsive in meeting increasing demands from the public. As a result, local governments are continually forced to levying of non-property taxes and fees (Steiss et al, 2011,).

Developing countries revenue growth is hampered by a combination of local government insufficient taxing authority and weak revenue sources. As a result there is a huge gap between the revenue collected and the forecasted (Bird and Mika, 1992).

Moreover, decentralization has given autonomy to raise revenue spending decisions to the lower tiers of government. However, the implementation of such administrative provision has a daunting task for many developing countries of local authority In a similar manner, in Ethiopia, though decentralization has been under implementation since 1991, nonetheless, revenue raising and expenditure management are not efficiently and effectively exercised, especially at lower tiers of government. This has led to financial incapability to satisfy infrastructural needs and deliver quality service to the public (Edison. et al, 2010). Even though Halaba special woreda manages revenue granted from the regional government, revenue collected from the rural land use and telethon, the woreda level administration does not face as such a huge budget deficit as town administration does. Thus, the study is aimed at assessing factors affecting revenue management of Halaba special woreda town administration which delivers a wide range of public service to the society. The town administration since the last three consecutive years has been facing budget deficit like other municipalities of developing countries. As a result, the following problems are frequently faced:

1. Lack of awareness of tax payers

2. in adequate assessment of taxable sources

3. Absence of clear operational guideline and 
4. Poor planning (town administration report, 2006) this can be considered as the cause for an average budget deficit of 3,055684 from 2004-2006in Halaba special woreda town administration as presented above in the table (Town Administration report, 2006)

\begin{tabular}{|l|l|l|l|l|l|l|}
\hline \multicolumn{1}{|c|}{ Year } & \multicolumn{1}{c|}{$\begin{array}{c}\text { Total } \\
\text { budget }\end{array}$} & \multicolumn{2}{c|}{$\begin{array}{c}\text { Revenue collected } \\
\text { From internal source }\end{array}$} & Difference & \multicolumn{2}{c|}{$\begin{array}{c}\text { Budget coverage } \\
\text { source planned in \% }\end{array}$} \\
\cline { 3 - 7 } & & Planned & Collected & & Grant & $\begin{array}{c}\text { Internal } \\
\text { source }\end{array}$ \\
\hline 2004 & 27,970000 & $8,000,000$ & $7,604,720$ & 395280 & 71 & 29 \\
\hline 2005 & $35,810,600$ & $17,600,000$ & $13,008,668$ & 4591332 & 51 & 49 \\
\hline 2006 & 47,779325 & $20,000,000$ & $15,819,560$ & 4180440 & 58 & 42 \\
\hline Total & $111,559,925$ & $45,600,000$ & $36,432,984$ & & 60 & 40 \\
\hline Average & 37186641.7 & 15200000 & 12144328 & 3,055684 & 60 & 40 \\
\hline
\end{tabular}

Source: Halaba special woreda town Administration (2004-2006) yearly report

They also resulted in the mismatch between the revenue demanded and the revenue at hand which led to a severe public service shortage manifested in the inability to provide land for lease, constructing youth recreation centers and stadium in Halaba Special Woreda Town. Due to these, the study is aimed to assess factors affecting public sector revenue management in the case of Halaba special woreda Town administration.

\subsection{Research Questions}

1. What are the major factors that affect revenue collection in Halaba special woreda town administration?

2. What are the factors to be taken into account for revenue planning in Halaba special woreda town administration?

3. To what extent does revenue management mechanism help in the town's revenue mobilization of Halaba Special woreda town administration?

\subsection{Objectives of the Study}

\subsubsection{General Objective}

The general objective of the study was to assess factors affecting public sector revenue management of Halaba special woreda town administration and propose possible solution based on the findings of the research.

\subsubsection{Specific Objective}

a) To identify the factors that affect revenue collection in Halaba special woreda town administration.

b) To identify the factors taken into consideration for revenue planning in Halaba special woreda town administration.

c) To know the extent of revenue management mechanism help in town revenue management.

\subsection{Significance of the Study}

The revenue management of Halaba town is inefficient and ineffective. As stated earlier, revenue management has a great role for any nation's economic development, no doubt how much decisive to solve the problem accompanied with it. Thus this study is believed to be more important by making an insight into the existing gap and suggest possible solution to for identified problem of revenue management output. This study will be a useful input to the following groups. 
1. To the town administration. To mitigate factors that hinder revenue management and enhance factors that promotes revenue management strategies.

2. To government of the Halaba special woreda: the output of the study serve as valuable source of reference to government generally, and ministry of finance especially, in policy making decision concerning revenue management of the town administration

3. To researcher conducting similar researches; the study can serve as a reference for researchers who are interested to carry out further study on the area.

4. To the taxpayer: as the study will identify the cause the problem, it will contribute raising the awareness of taxpayers to understand their role and discharge their responsibilities properly.

5. Finally, the outcome of the study has an important contribution on revenue management reform going on state and town administration of Halaba special woreda.

\subsection{Scope of the Study}

The study was carried out in Halaba special woreda town administration level. It was delimited to the Halaba special woreda town administration due to the continuous revenue management problem in the study town administration. On the other hand, problem of revenue collection deserves an inquiry to find out the level of vulnerable to corruption, which is chronic problem at the study town administration level. The study is also delimited in its scope in terms of time from 2004-2006.Finally, shortage of time and finance are the cause for the delimitation of the study.

\subsection{Limitation of the Study}

The time allocated for the study was short so that it was difficult to assess all the factors that affect revenue management with in the Town administration. During the data collection process, the quality of the output of this study has been contingent on the adequate availability of secondary data of the revenue and genuine responses from the respondents. But the respondents may not give what is in their heart because they suspect that they will face problems from their bosses or unwillingness of the respondents to give possible answer for the Questionnaire delivered. Likewise some bureau officers try to cover the weakness of their bureau and focuses on their strong side. And also some respondents were not punctual in returning the questionnaire. The researcher overcomes the limitations by memorizing the confidentiality of their comment as indicated in the preamble of the questionnaires as a solution for their about their comment whereas for their punctuality problem the research gave additional time to fill the questionnaires.

\subsection{Organization of the Paper}

Chapter one is about the introduction of research background, the statement of the problem, research questions and objectives, scope and significance of the study .moreover it contains organization and limitation of the paper. The purpose of introducing the research background is to aware the history of Revenue management that will help to have deep knowledge about the issue. Introducing statement of the problem will help to have deep knowledge about the criticality of the research problem and gives detail information about the rationality of the study issue. The objective of the research objective is to help us to gear our efforts towards research target that means to assess factors affecting Revenue management of Halaba special woreda Town Administration and suggest possible solution. The purpose of research questions is to introduce the existing factors which require be identifying and solving, Significance the study is to introduce the importance of research output. The purpose of scope of the study is introducing the coverage of the research. Chapter two contains literature review. It provides background information and justification for the research under study besides it will help us to understand the gap identified by previous researchers and understand the gaps of previous researcher. Chapter three is about the research methodology it deals with the various steps that are generally adapted by the researcher. It also deals about not only the methods but also the justification for the relevance of the methods. Chapter four contains data analysis, Interpretation and Discussion. Chapter five contains Findings, conclusion and recommendation. 


\subsection{Definitions of Key Terms}

Income tax: Tax governments impose on the amount one earns either from work or investment (Mikesell, 2003)

Turnover tax: a tax imposed on the value of property (Steiss, 2001).

Value added tax: a tax imposed on consumption (ibid, 2003).

Regional state: Federal democratic republic of Ethiopia regional state (FDRE Constitution of 1993).

Tax base: is an event on which revenue is collected (public financial management ppp, 2007).

Excise tax: the tax imposed on consumption to discourage certain types of goods (Steiss, 2001).

Urban local government (ULG): Authorized body which has power to determine on administrative financial and legal dimension (Mirjam, 1995).

Taxpayer (Business person); Individuals who engaged in business activities and have the responsibility to pay tax (researcher)

\section{CHAPTER TWO}

\subsection{Review of Related Literature}

\subsubsection{Public Sector Revenue Management}

Public sector revenue management is the sub set of financial management which focuses on revenue generating and spending for various development programs designed to achieve organizational goals. Governments normally collect revenue through their sovereign taxing power to define the payment owed without any connection to the value of any public product or service received by the taxpayer (Finkler, 2005). Revenue Management enables for Local government authorities to optimize the revenue collection process and efficiently manage ever changing tax law and legislative changes associated with revenue (Oracle, 2011).Moreover, it is comprehensive solution which provides a configurable alternative to custom built systems and helps leverage existing investment and control costs. The result is a costeffective solution that will result in improved revenue generation, tracking, compliance, and taxpayer service (Ibid).

\subsubsection{Importance of Public Sector Revenue Management}

Revenue management plays a vital role for overall financial solvency. Any capital improvement program must be formulated within the financial capacity of government to pay for its needs and desires. A community that cannot meet its short term public expenditure demands from existing sources of revenue will have great difficulty in securing willing investors for its long term bonds. Under such circumstances, investors are likely to demand higher interest rates to offset risk (Steiss, 2001). Developing countries in general and Africa in particular have been facing a number of challenges that they must overcome so as to make progress in social, economic and political development. These challenges tend to determine the development priorities, capacity, and commitment of the developing countries government to deal with public affairs (Amanuel, 2013). Dealing with public affairs needs in huge amount of revenue. Providing such sufficient amount of revenue can be achieved by effective and efficient management of revenue sources and spending pattern. According to Bailey (2004) cited in Gondo T et al (2010) constantly reviewing the patterns of spending is essential to ascertain the fulfillment of targeted objectives. Hence, achievement of planned objectives with planned expenditure can be used to evaluate whether the expenditure system is effective or not so that revenue will be saved.

Moreover, Effective tax collection and revenue management represent the financial life lines of government. Without sufficient revenue, federal, state, and local agencies cannot deliver the essential services taxpayers, citizens and constituents expect and need (www.sap.com/) public sector).It is also the means to consolidate and optimize business and systems processes to maximize revenue realization and 
minimize cost per dollar collected (foundation of tax administrators, 2003). Furthermore, revenue management also interacts closely with expenditure management during determination of the overall budget envelope and managing in year cash Flow (MOFED, 2012).Nice (2002) states that by monitoring and analyzing revenues on an ongoing basis, officials can detect problems early. This in turn may enable officials to begin taking corrective actions early and prevent avoidable damage. As indicated by different scholars, regarding revenue management, as it play as vital role for ensuring the achievement of the intended purpose through wise utilization of the resource available for that purpose. In addition, if there is effective and efficient revenue management financial solvency can be achieved or addressed. As is known financial solvency requires the abilities of organizations to meet the long and short term financial needs. It also guarantees access to other resources otherwise not. Hence revenue contributions to the overall nation's development can be ensured.

\subsubsection{Principles of Public Sector Revenue Management}

Public sector revenue management solution offers a complete set of features and functions to address the needs of government authorities responsible for the administration of revenue law and policy (www.cefims.ac.uk/documents/sample-34.pdf). The following are some of the principles of revenue management.

a) Public revenue management related regulation should exist. Accounting can be perceived as a neutral tool for revenue control. Accounting in addition to technical aspects, such as bookkeeping and liquidity management, it also provides guidelines for political assessments and how the administration of public services takes place, and they trigger growth (Veggeland, 2009).

b) National and international standard and guidance on best practice should be applied.

c) Fair and equitable distribution of tax burden; applying ability to pay and benefits principle. According to Tanzi (2003) peoples tax payment should be in line with their income and they are required to pay a tax in proportion to their level of income on the other part of tax collectors, collection of revenue should be time conscious and convenient and the cost of collecting the taxes should not be high to discourage Business.

d) Revenue neutrality. An important economic principle in the design of taxes is that taxation should be" neutral". "Neutral" (in the economic sense) means that the tax does not alter the decisions about investment, production, consumption and trade that would be made in the absence of the tax unless the tax is deliberately intended to do so.

e) Revenue management should ensure revenue productivity. the main functions performed by revenue management cover the following areas:-

I. Planning for future income levels including the determination of income sources and tariffs;

II. The physical collection of revenue through the cashier system;

III. Accounting for revenue collected in the government accounting system,

IV. Ensuring safe and secure arrangements for handling cash and transferring it to government bank accounts (Explanatory Note, 2002).

a) Efficient and effective revenue management skill should be employed. Once a budget has been approved by the legislature, the government embarks on the challenging task of spending funds. Spending public funds effectively to meet stated policy objectives while ensuring value for money is often just as challenging (if not more so) than planning how to spend it. Several reviews of PFM performance in developing countries show that countries score significantly better on revenue preparation than on revenue execution indicators (Andrews, 2008). identification of manager with potential and assume a greater responsibility in the Staff training and development is process for developing and allow running free human expertise through organization development and personnel training and development for the purpose of improving performance hence it will increase employees commitment (Swanson R. A, 2001). This is achieved through; 
i. Recruitment and selection; it is a process of attracting a qualified job applicant in a sufficient amount and choosing the one among the applicants who best fit to the given job (HRM reader, 2013).

ii. Performance management; performance management helps for a manager to measure weather the set objective is achieved or not (Ibid, 2013) so that managers motivate employees according to their performance based on the needs of employees.

iii. Career planning; is a sequence of attitudes and behavior associated with the services of job and work related activities over a person's life time .it will help for the organization to retain qualified personnel.

iv. Succession management; It is the process for identifying and developing employees with the potential to fill key roles within the organization. Through the succession planning process, an organization recruits superior employees, develops their knowledge, skills, and abilities, and prepares them for advancement or promotion into ever more challenging roles. Succession planning increases the availability of experienced and capable employees that are prepared to assume key roles as they become available (achievement mission, 2013)

The principles of revenue management implemented and enforced through detailed procedural rules specifying the scope of the budget, the information to be included in it, the timetable for taking particular actions, the forms to be used, the authorization required before public funds are spent, and soon. Every principle is backed by formal rules which are enforced by revenue controllers at the center of government and in the spending departments. The accumulated principles and procedures comprise due process in revenue management (Schick, 1999).

If the above principles are properly implemented it will result the Achievement of the intended purpose through wise utilization of the scarce resources as well as it will increase public confidence on the government. Proper utilization of revenue has social, economic and political benefits. Socially, as is known some revenues are allocated for social welfare program, like, Education, Health and others. If the revenue allocated for social welfare is properly utilized, social objective will be ensured. Economically it will motivate tax payers because they will believe that their contribution has value for money and as well as return for them in the form of public services, it further guarantees for the government access to others resources. Politically, people vote for those governments who discharged their promises during election (researchers' observation).

\subsection{Challenges of Public Sector Revenue Management}

The increasing complexity of the public administration environment and the continuous need to align the needs of society with limited resources require that funds are made available for a specific purpose and used for that purpose. However, in developing countries, specially, in Africa there are many problems regarding utilization of the available resource for the intended purpose. As a result, the following weaknesses are frequently observed.

1. Poor planning having no links between policy makings, Planning and budgeting:

2. Poor expenditure control

3. Inadequate funding of operations and maintenance

4. Little relationship between budget as formulated and budget as executed

5. Inadequate accounting system

6. Unreliability in the flow of budgeted funds to agencies and lower levels of government

7. Poor management of external aid.

8. Poor cash management

9. Inadequate reporting of financial performance and poorly motivated staff (the World Bank, 1998). 
The entire above are challenges of public sector revenue management so in order to achieve efficiency and effectiveness in revenue management, the challenges should be mitigated. Therefore, revenue management must consider all of the above issues in the form cost benefit analysis to maximize return on revenue.

\subsection{Factors Affecting Revenue Collection}

Revenue collection is one of the main functions of local governments. Local governments collect funds from a variety of revenue sources, including fines, fees, taxes, licenses, permits, and special assessments. Collection requires both the efforts of the government and the taxpayers. According (Shah, 2007, p34,) collection procedures should answer that payment of liabilities is enforced and that actual payments are brought fully to account procedures should be clear and applied for all taxpayers. Revenue should be received in timely manner, credited to the proper fund, and deposited into the correct Bank account as quickly as possible (Ibid).

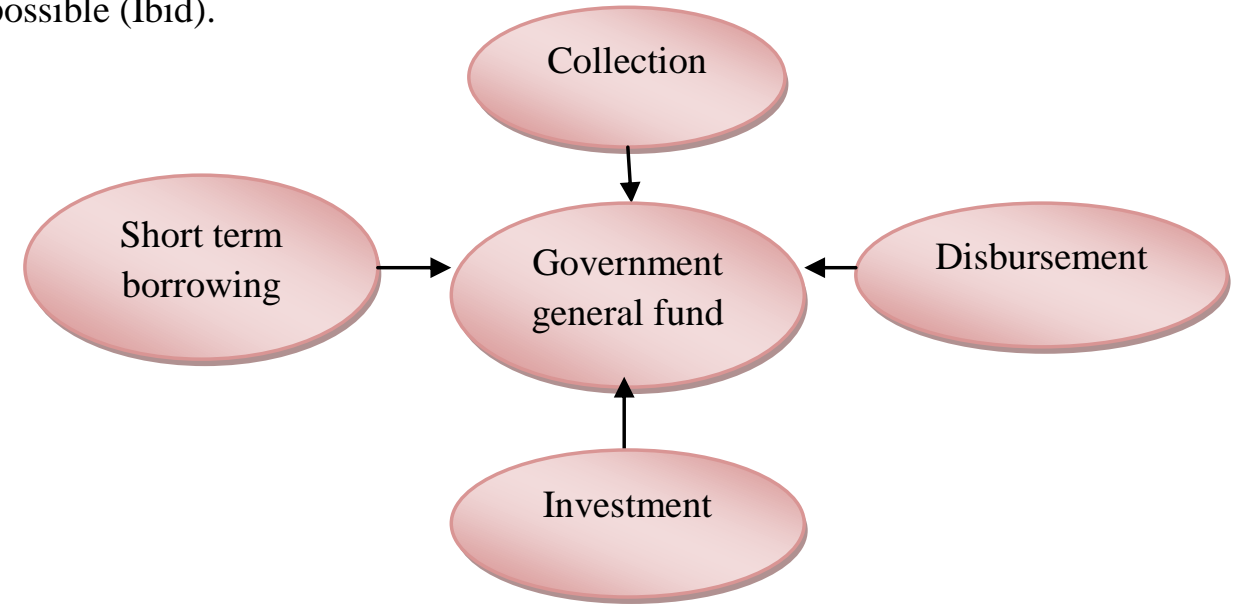

Source Anwar Shah (2007, p.35)

Figure 2-1 Cash Management

\section{a) Collection Methods}

Collection method affects collecting monies owed in a variety of forms, such as coin and local currency, paper checks, credit card charges, an automated clearing house. Each form of the collection has its own merits. For example, if we take, receiving revenue in the form of coin and currency, it allows government to use the revenue immediately in order to meet its financial needs without any additional cost (Shah, 2007). The other form of collection methods incurs costs as compared with coin and currency. For example, receiving revenue in the form of paper checks the most common means of paying obligations of local government typically accepts checks over the counter and by mail. Checks should be deposited in the bank the same day they are received. Depositing checks the day they are received helps to expedite the availability of funds by getting the checkers into the Federal Reserve payment system as quickly as possible. A drawback to accepting checks is the risk of bad checks that will be a costly and time consuming activity for a local governments staff (Shah, 2007). Gainakis and Mccue (1999) argue that the efficiency revenue source refers the cost of collecting it including the compliance cost borne by the payer.

\section{b) Accuracy and Time Lines of Reporting}

One of the most important components of any revenue collection system is accurate and timely reporting. Local governments need revenue management software that allows revenue collection staff to update records frequently. According to ERCA(2008) as cited by Mukhtar (2014) revenue accounting involves timely recording of collection, recording payments to individual tax payer's files to appropriate accounts, reports and review the accuracy of regulatory information. Revenue accounting facilitates refunds, bank reconciliation, and revenue sharing between regional and federal government. 


\section{c) Tax Base}

Tax revenue can be increased by increasing the tax base which means including or redefining previously exempted tax. A different choice of assessment methods can increase the assessed value to collect more taxes (Wong, 2006). This is done when the increase in tax rate is not enough to cover the budget gap.

\section{d) Tax Rate}

Tax rate also affects revenue collection. The increase in tax rate has positive impact on revenue collection, as a result, local property tax rates changes often .Nevertheless, if there is a large revenue shortage, and small incremental adjustment of the tax rate may not be enough. As a result, developing new taxes is need (Wong, 2006).According to Giugle and Webb (2000),sub national governments must have adequate revenue to cover their spending not only changing tax rates but also imposing new taxes. All of the listed are major factors that affect revenue collection either positively or negatively. Effective revenue management will capitalize positive factors and mitigate negative factors.

e) Types of tax: Revenue is affected by types of bases and its administration nature (Mikesell, 2003). Some taxes can easily be collected, some are difficult or require high effort.

f) Procedures: if revenue enforcement procedure not properly implemented and revenue evaders are not strictly controlled to pay their tax as per the schedule, this is accompanied with due to lack of clear guidelines and inadequate management system.

g) Attitude: Revenue collection is also impeded by public attitudes towards public revenue (Yousuf, 2012) .if public attitude towards public revenue is positive it will have positive impact on revenue collection. If attitudes towards public revenue are negative the impact on revenue collection will be negative from researcher's observation.

\section{h) Compliance Handling}

An effective and efficient program of taxpayer service activities is a critical objective of all revenue bodies. It helps for saving cost of revenue collection and will help reducing the gap between what taxes should be collected and what is actually collected.

i) Mechanisms for identification and registration of taxpayers; taxpayer's recognition and registration is a foundation for other tax administration for tasks, according to (Bird and Zolt, 2004), it should establish a system to register non voluntarily taxpayers' registration function of tax administration organization absorbs finding out potential taxpayers for tax objectives and registering them as taxpayers in a central data base. A good tax administration identifies and registers all traders who are liable to register for the tax, according to article 43 of the income tax proclamation," Every person having a taxpayer identification number ("TIN", but in no case may a person obtain more than one "TIN".

\subsection{Factors Taken into Consideration for Revenue Planning}

According to Finkler (2005), undertaking the common sense of review of the likely impact of the economic environment of the organization is important. Giugle and Webb (1999) state that revenue managers should examine the equity of their revenue structures in light of the distribution of goods and services provided, and the efficiency of their revenue sources in terms of costs of compliance, the costs of administrations, and their effects on private economic activity.

\section{a) Identifying Source of Revenue}

All governments face political, legal and economic realities which constrain their efforts to draw resource from their communities. The extent to which the economic base can be tapped by a government within these constraints is the organization's revenue capacity, often referred to as fiscal capacity (Finkler, 2005, p564). Revenue management is a process of identifying and analyzing sources and amounts of government revenues such as taxes, income from natural resources, loans and grants, and Assessing the fairness and efficiency of revenue generation. According to Tanzi (2000) people's tax payment should be in line with their income and they are required to pay a tax in proportion to their level of income on the 
other part of tax collectors, collection of revenue should be time conscious and convenient and the cost of collecting the taxes should not be high to discourage Business. Such as for example, the systems of taxation and the management of natural resources. Together with public revenue reporting, monitoring of public revenue acts complementary to monitoring public budgets, and tracking what the government does with that revenue. It allows citizens and civil society to question how governments mobilize financial resources and how those resources are utilized.

The main sources of public revenue are:

i. Taxes and levies such as for e.g. income tax, property tax, sales tax, license fees, import and export duties, levies charged for services etc. (University of Landon,2012.p8)

ii. $\quad$ Earnings from natural resources like oil, gas, minerals (University of London, 2012,p4,)

iii. Loans from other governments, the private sector, or international financial institution (University of London, 2012,p9,)

Grants-in-aid from other governments, multilateral institutions, international donors Public revenue reporting serves to inform the citizens of the sources and amounts of government revenue and how it is proposed to be utilized. It also forms the basis for public revenue monitoring which aims to ensure public revenues are properly managed. By complementing the task of tracking public budgets and expenditure, public revenue reporting and monitoring plays a crucial role in holding the government accountable for its decisions and actions (Malena et al, 2014).According to Anderson (2003) revenue also include receipts of the government from parties outside the government, primarily from not only tax but also from fees and other sources.

One of the major developmental issues facing many countries, governments and business entities is the issue of good financial management. Ensuring good financial management

- Identifying the sources if the sources appropriately identified it has positive impact on planning because of it may lead as proper planning.

- The collected data regarding the identified sources revenue potential should be relevant and valid.

- Forecasting method applied: It affect revenue planning even if the collected information is valid and relevant sometimes inappropriate revenue forecasting method will lead poor planning. Public infrastructure investment and efforts to improve the doing business condition,

- Inflation: Inflation erodes the real value of debts, so borrowers are made better off relative to savers or creditors. As the government is usually the major debtor dealing with inflation plays an important role for revenue management (Yueh, 2006, p315).If there is inflation the cost of the government to provide public service will increase hence reduce revenue.

- Financial sector stability: if the financial sectors are not stabilized it is difficult for the government obtain the planned revenue.

- Risks: that arises from the uncertain prospects for global economy which could affect the government revenue.

- Foreign exchange reserves: They are set up primarily to insulate the budget and that means saving during a revenue windfall and consuming during a price slump (V.K. Bhalla, 2008.p598). Low foreign exchange reserves affects level of liquidity it is the primary monetary policy tool to affect the level of liquidity.

- Balance of payment: It is simply one nation's account with the rest of the world. It describes and sums all the transactions the residents of one country make with residents from other countries. Sales of goods, services, physical capital and financial assets from domestic to overseas residents are credits on the balance of payments. The reverse, purchases by domestic residents from those overseas, are recorded as debits (Yuehet al, 2006,p358). 


\subsubsection{Problems of Public Sector Revenue Planning}

The foundation for any budget process is the forecasting of the revenue available to support the activities of the government or business for the budget period. For state governments forecasting revenues is particularly difficult because of many independent and largely uncontrollable variables that influence the revenue realized from the particular sources. Some of the variables frequently affecting are;

i. Unpredictable event. Unpredictable event affect revenue planned. For example, increase in inflation rate may raise the cost of goods and services reducing revenue planned. Natural disaster such as flood, draught may result the government unplanned expenditure.

ii. Poor revenue forecasting is a result of lack of data or forecasting method applied, as a result poor forecasting there may be underestimation of revenue which result lack of revenue to provide goods and services to the public or over estimation of revenue which result underutilization of revenue. The government institution should have optimal amount of revenue. If there is over estimation of revenue there will be surplus that will result underutilization of revenue. As is known revenue are scarce the more surplus revenue in one government sector will limit the revenue available for other sectors of the government as it is drawn from the same pocket. This leads inefficient utilization of revenue. Revenue forecast predicates the revenue baseline, estimates what revenue will be collected in the budget period under the current law. It includes forecast of economic, political, demographic, administrative and other factors of tax collecting environment (Mikesell, 2007).

\subsection{The Roles of Management Tools and Techniques in Revenue Mobilization}

Management tools and techniques play a major role in revenue mobilization. If an administration has no full autonomy in personnel matters, its ability to set performance and accountability standards for its employees would be undermined in most cases (Bridi, 2010). The management tools and technologies should have to allow policy of transparent recruitment, sufficient remuneration, pension schemes accompanied by a policy of attracting, retaining and motivating based on qualification and performance (Ibid).in order to achieve efficient and effective revenue mobilization we need to retain and motivate qualified revenue officers, through establishing clear career paths need to be set out so that qualified officers view the revenue profession as preferred career choice (Yousuf, 2012).If there is clear and defined procedures revenue mobilization and reward system, employees will be motivated to perform according to the procedures because if employee are treated fairly and they are rewarded for their better performance they feel sense of ownership and responsibility and perform activities accordingly (Swason. et al 2001). 
Figure 2.2: Factors affecting public sector revenue management

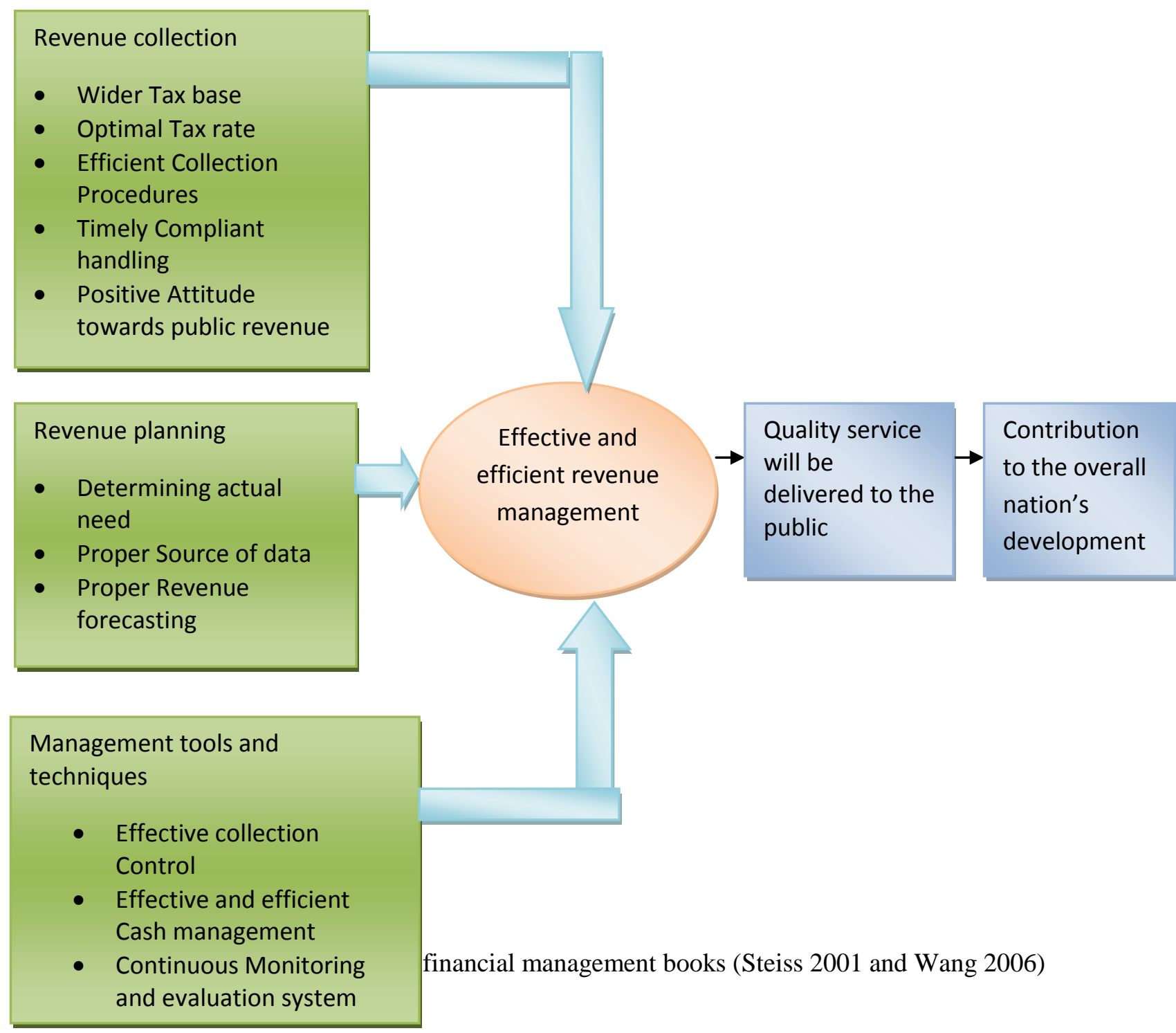

\subsection{Empirical Literature}

According to Ndemanyisho (2014) Studies carried out in Tanzania on Revenue generation, revealed that revenue collection is affected by absence of revenue accounting system and mechanism to reach taxpayers and the limited tax revenue administration knowledge about potential taxpayers in the informal sector economy and inadequacies in exploiting information communication technology to enhance efficiency are few that inhabit revenue collection In same vein, Mbilityi and Mutalemwa (2010) outline the challenge facing collection of income tax in Tanzania and these include; lack of reliable records on the number of taxpayers ,public records and statistics for taxation, inadequate knowledge of keeping records in sales transactions and receipting by registered taxpayers.

Similarly, Gondo T et al (2010) studies on fiscal management carried out in Ethiopia, in the case of Dangila Municipality revealed that Municipality revenue collection is affected inadequate assessment of 
taxable sources, lack of awareness of taxpayers, inadequate accounting system and lack of skilled manpower are identified as factors affecting revenue collection. Moreover, studies carried out in Harergeigesa city by Yuosuf (2012) revealed that tax collection is affected by the attitude of tax collectors, quality of services and awareness of tax payers. However Studies undertaken in Dangila, Tanzania and Harergeisa city focuses on factors affecting tax revenue collection, however, Revenue management not only concerned about factors affecting tax revenue but also non tax revenue collection. Moreover, it deals with factors taken in to consideration for revenue planning and the role of management tools and techniques to revenue management .Since all have an impact on public sector revenue management performance. Furthermore, there are few researches done on public sector revenue management in general, no research done on public sector revenue management in Halaba special woreda in particular. In addition to that there is revenue management problem in Halaba special woreda Town administration. As a result, the study aimed to address the issue.

\section{CHAPTER THREE}

\section{Research Design and Methodology}

\subsection{Description of the Study Area}

Halaba woreda is located $315 \mathrm{kms}$ south of Addis Ababa and about $85 \mathrm{~km}$ south west of the Southern Nation Nationalities and Peoples Regional (SNNPR) state capital, Awassa. The woreda is geographically located $717^{\circ} \mathrm{N}$ latitude and $3806^{\circ} \mathrm{E}$ longitude. It is located west of Oromiya region, north of Hadiya (sika), east of Kembata Tembaro, south east of silte and Hadiya zone. It is a special woreda and has special status where the administration directly reports to the regional state. There are 79 rural kebeles/villages and 3 sub-cities in the woreda. Halaba kulito is the capital of the waredas, is believed to have been founded towards the end of the 2oth century (Alabapilat survey, 2005). According to census made during 2004E.C the population of Halaba is estimated to be 271,000 with an area of 91,230ha. The woreda is found in Winadega climatic zone with the mean annual temperature ranging between $23-25 c^{\prime}$ and the mean annual rainfall between 700_900 mm. The woreda is located at an altitude of 1554 to 2149 m.a.s.1, but most parts of the woreda is found at about 1800 m.a.s.l .the land use pattern shows that out of the total area coverage of the woreda64116hector 44020 hector is currently cultivated, 4317 hector is used for grazing, 3644 hector is cultiviabl, 4592 hector forest covered, 4737 hector for others and the rest about 2805 uncultivable land.

Mixed agriculture is the main activity and trade also plays an important role in the woreda with Alababa ethnic group as the dominant in number. The woreda has regional Markets, namely, Halaba kulito and village Markets named as Guba, Besheno, Kobo, among these Halaba kulito is the biggest. Maize is the most common food crop followed by teff, wheat, sorghum, barley and haricot bean are produced in the Woreda. The woreda is reckoned for the high quality red pepper production which is mainly supplied to Addis Ababa and other parts of the country.

\subsection{Research Design and Methodology}

The study used a descriptive design method because it was appropriate to identify factors and it described what already existed and happening now. It was used to identify factors that were really affecting public sector revenue management in Halaba special woreda town administration and suggested possible solution based on the findings of the study.

\subsection{Source of Data}

For the accomplishment of this research, the study applied both primary and secondary sources of data. Primary data; the data that was collected for the first time by the researcher. The study collected this data through questionnaires, interviews, and focus group discussion and observation method. Secondary data; was collected from different sources such as public revenue management documents, books, journals, articles, internet sources, reports etc. 


\subsection{Population, Sample Size and Sampling Technique of the Study}

\subsubsection{Population, Sampling Unit, Sampling Frame, Sample Size and Sampling Technique}

The study employed both probability and non-probability sampling techniques. Probability sampling was employed selecting employees and taxpayers. Whereas, non-Probability sampling techniques were employed for purposive sampling. To this end, four public officials were purposively selected for interview from Mayor Committee and Inland Revenue office management committee members were taken purposively for focus group discussion, while employees of the town administration and tax payers had included in the study using random sampling. The study took four public officials from Mayor Committee members to be interviewed and Inland Revenue management committee members (7) for focus group discussion on assuming that they have enough information about Halaba special woreda town administration's revenue management.

Table 3.1: Demography

\begin{tabular}{|l|l|l|l|l|}
\hline \multicolumn{1}{|c|}{ Target group } & Population & Sample size & \multicolumn{1}{c|}{$\begin{array}{c}\text { Distributed } \\
\text { questionnaires }\end{array}$} & $\begin{array}{c}\text { Returned } \\
\text { questionnaires }\end{array}$ \\
\hline Employee & 336 & 88 & 88 & 80 \\
\hline Taxpayers & 151 & 67 & 67 & 64 \\
\hline Mayor committee & 6 & 4 & 4 & 4 \\
\hline $\begin{array}{l}\text { Inland revenue } \\
\text { management committee }\end{array}$ & 7 & 7 & 7 & 7 \\
\hline Total & 500 & 151 & 166 & 155 \\
\hline
\end{tabular}

Source: Own survey, March, 2015

\subsubsection{Population}

The populations of the study were all government employees of the town administration and Taxpayers (Business people) of the same.

\subsubsection{Sampling Unit or Units of Analysis}

The sampling units or a unit of analysis of this study was tax payers who were registered in the Inland Revenue office and government employees who were working in the town administration.

\subsubsection{Sampling Frame}

The sampling frame for tax payers' includes the list of registered tax payers in the Inland Revenue office of Halaba special woreda town administration, whereas, the sample frame for employees was list of employees' of Halaba special woreda town administration.

\subsubsection{Sampling techniques and Sample Size}

For the purpose of this study, the employees were categorized in to two groups; these were employees and tax payers. From these the study drawn randomly its each sample unit from stratum just like a lottery means first I took employees list from civil services department of the Town administration then I wrote from 1-336 numbers on 336 pieces of paper I picked up one at a time randomly till it became equal to the sample size (88) drawn from that category of population (employees) the same procedure was applied for population (taxpayers) two. The study employed stratified sampling method in order to incorporate 
sampling unites from each population categories in the sample and ensure more representatives of the population.

The study was categorized the target population in to employees and tax payers of the town administration. Accordingly, the study was included the sample from each category or from each stratum. Stratum is the population category from which the sample is drawn.

$\mathrm{N} 1=$ employees of town administration which is=336 and tax payers whose number is 151 which is $\mathrm{N} 2$

According to Corbetta as cited by Rahel (2012), for the population less than 10,000 to determine the sample size we can use the formula;

$f_{n}=n / 1+n / N$

Where $n=\frac{Z^{2} P Q}{d^{2}} \quad \frac{(1.75)^{2}(0.5)(1-0.5)}{(0.08)^{2}}=120$

Here $\mathrm{N}=\mathrm{N} 1+\mathrm{N} 2$, hence we need to do sample size from both population; that is

$$
\begin{aligned}
\mathrm{f}_{\mathrm{n}} 1= & \frac{n}{1+n / N 1} \\
\mathrm{f}_{\mathrm{n}} 2=\frac{n}{1+n / N 2} & \frac{120}{1+120 / 336}=88 \text { Government employees }
\end{aligned}
$$

The total sample size is $=88+67=155+7$ purposively selected management committee members +4 public officials $=166$

Where $\mathrm{N}$ is total population

$\mathrm{n}=$ the desired sample size

$\mathrm{Z}=$ the standard normal deviation at required confidence level is set at 1.75 which corresponds to $92 \%$ confidence level

$\mathrm{p}=$ the proportion in target population estimated to have a desired characteristics, if there is no reasonable estimate, then 0.5 perfect use as acceptable level

$\mathrm{Q}=1-\mathrm{p}$; and

$\mathrm{d}=$ Level of statistical significance at 0.08 .

\subsubsection{Data Collecting Tools}

The study was employed questionnaires in order to obtain accurate information about the extent of Knowledge and attitudes government employees and tax payers had on factors affecting Halaba special woreda town administration's revenue management which involved both opened and closed- end questions were employed in order to obtain answers on standardized questions and to be able to compare the answers from person to person .open ended questions were employed in order to allow the respondents to give adequate answers and to obtain additional information regarding, factors affecting revenue management of Halaba special woreda town administration which was not included in the close ended answer category. Structured interviews were employed in order to obtain answers on standardized questions and to be able to compare the answers from person to person. 


\subsubsection{Methods of Data Processing and Analysis}

The data collected through questionnaire were recorded, edited, organized, analyzed, interpreted and presented based on research questioners through applying descriptive statistical tools, such as SPSS, tables, figures, percentages, graphs, charts for data collected. For the qualitative data, description, analysis and interpretive techniques were used to supplement data obtained through quantitative instruments.

\section{CHAPTER FOUR}

\section{DATA ANALYSIS AND INTERPRETATION}

\subsection{Introductions}

This chapter deals with the data analysis, discussion, findings and interpretations of the study. The response rate of the respondents are at the beginning of this chapter, More topics are discussed which reflected the objectives of this research such as discussing factors affecting revenue collection in Halaba special woreda town administration, In addition, identifying factors taken into consideration for revenue planning in Halaba special woreda town administration and the level of revenue management, its contribution to the improvement of Halaba special woreda town administration will be treated in detail.

\subsection{Demographic Data}

Table 4.1: Age of Employees

\begin{tabular}{|l|c|c|c|}
\hline \multicolumn{1}{|c|}{ Alternatives } & Frequency & Percent & Cumulative Percent \\
\hline $20-30$ & 41 & 51.2 & 51.3 \\
\hline $31-40$ & 22 & 27.5 & 78.8 \\
\hline $41-50$ & 12 & 15 & 93.8 \\
\hline$>50$ & 5 & 6.3 & 100 \\
\hline Total & 80 & 100 & \\
\hline
\end{tabular}

Source: Own survey, March, 2015

\subsubsection{Age of employees}

From the 80 returned questionnaires from employees, 51.2\% were found under age of 20-30 and 27.5\% were found under age of 31-40.In addition, 15\%were found under age of 41-50, while $6.3 \%$ were found under the age of above50. from this fact we can understand that the majority $(78.8 \%)$ of employees are young and Moderately young age group which will enable for the town administration to adapt change easily, for instance, If the town administration wanted to introduce new technology which promote the efficiency and effectiveness of revenue management, it easily Convenes and prepare employees for implementation. As is known, young people need and adapt change easily than older people. In addition, having this age group will increase the probability to obtain innovative individuals who can in turn play a great role for minimizing factors affecting revenue management negatively.

Table 4.2: Educational Status of Employees

\begin{tabular}{|l|c|c|c|}
\hline Alternatives & Frequency & Percent & Cumulative Percent \\
\hline Certificate & 5 & 6.3 & 6.3 \\
\hline Diploma & 8 & 10.0 & 16.3 \\
\hline Degree & 60 & 75.0 & 91.3 \\
\hline Masters & 7 & 8.8 & 100.0 \\
\hline Total & 80 & 100.0 & \\
\hline
\end{tabular}

Source: Own survey, March, 2015 


\subsubsection{Educational Status of Employees}

As presented above in table 4.2 data of Educational status of employees, $6.3 \%$ were certificate, $10 \%$ diploma, $75 \%$ degree and $8.8 \%$ were masters .This indicates that most $(83.8 \%)$ of them have attained degree and masters which shows high level of qualification of employees .hence, the town administration can increase the revenue management efficiency by filling skill gap, solving attitudinal problems and increasing the commitment of employees so as they can help for the achievement of revenue management objective.

Table 4.3: Work Experience of Employees

\begin{tabular}{|l|c|c|c|}
\hline Alternatives & Frequency & Percent & Cumulative Percent \\
\hline $1-3$ & 25 & 31.3 & 31.3 \\
\hline $4-6$ & 11 & 13.8 & 45.0 \\
\hline $7-10$ & 13 & 16.3 & 61.3 \\
\hline$>10$ & 31 & 38.8 & 100.0 \\
\hline Total & 80 & 100.0 & \\
\hline
\end{tabular}

Source: Own survey, March, 2015

\subsubsection{Work Experience of Employees}

As can be seen in table 4.3 above, $31.3 \%$ employees are between1-3 years, $11 \%$ are between $4-7,16.3 \%$ between 7-10 and 38.8\% have work experience of above 10 years. This shows that $55 \%$ of the employees have work experience of 7-10 and above 10 years which shows that the town administration has well experienced man power this will help for achieving revenue management objectives with low cost.

Table 4.4: Educational status of Taxpayers

\begin{tabular}{|l|c|c|c|}
\hline \multicolumn{1}{|c|}{ Alternatives } & Frequency & Percent & Cumulative Percent \\
\hline Secondary & 24 & 37.5 & 37.5 \\
\hline Certificate & 9 & 14.1 & 51.6 \\
\hline Diploma & 26 & 40.6 & 92.2 \\
\hline Degree and above & 4 & 6.3 & 98.4 \\
\hline Missed & 1 & 1.6 & 100.0 \\
\hline Total & 64 & 100.0 & \\
\hline
\end{tabular}

Source: Own source, March, 2015

\subsection{4: Educational status of Taxpayers}

As shown in the above data, out of 64 taxpayers $37.5 \%$ of them attained secondary level, $40.6 \%$ diploma level, $14.1 \%$ certificate, $6.3 \%$ attained degree and above.51.6\% of taxpayers attained secondary and certificate level. From this fact we can judge the level their critical thinking about importance of public revenue is low which in turn hinder revenue collection efficiency.

\subsection{Response Rate}

Response rate refers to the ratio of number of people who answered the questionnaire divided by the number of individuals in the sample and usually expressed in the form of percentage whereas law response rate introduces bias. for this study the researcher has distributed questionnaires with a sample of 166 individuals, and 155 questionnaires were returned out of 166.this indicated that $93 \%$ out of $100 \%$ questionnaires were collected while remaining 11 individuals did not returned the questionnaires.

Moreover, according to Yasin Nur (2012) and Mangione (1995) cited in Brymand and Bell (2003) asserts that response rate below $50 \%$ are not acceptable. Therefore, the total response of $93 \%$ of the respondents 
in this research is sufficient and possible to undertake research that deals with assessment of factors affecting revenue management.

\subsubsection{Factors Affecting Revenue Collection}

Revenue collection is one of the main functions of local governments. Local governments collect funds from a variety of revenue sources, including fines, fees, taxes, licenses, permits, and special assessments. Collection requires both the efforts of the government and the taxpayers. According to Shah,( 2007, p34,) collection procedures should answer that payment of liabilities is enforced and that actual payments are brought fully to account procedures should be clear and applied for all taxpayers. Revenue should be received in a timely manner, credited to the proper fund, and deposited into the correct Bank account as quickly as possible.

Table 4.5: What are the major revenue sources for the town administration?

\begin{tabular}{|l|c|c|c|}
\hline \multicolumn{1}{|c|}{ Alternatives } & Frequency & Percent & Cumulative Percent \\
\hline Value added tax & 18 & 22.5 & 22.5 \\
\hline Property tax & 2 & 2.5 & 25.0 \\
\hline Hawkers and traders tax & 54 & 67.5 & 92.5 \\
\hline Business license tax & 6 & 7.5 & 100.0 \\
\hline Total & 80 & 100.0 & \\
\hline
\end{tabular}

Source: Own survey, March, 2015

\subsubsection{1: Source of Revenue}

Revenue is affected by types of bases and its administration nature (Mikesell, 2003). Some taxes can easily be collected, some are difficult or require greater effort.

As shown in the above table 4.5 out of 80 respondents $22.5 \%$ said the major sources of revenue for the town administration is value added tax, $67.5 \%$ said hawkers and trader tax, $7.5 \%$ respondents said business license tax and $2.5 \%$ said property tax. Moreover, the interviewed mayor committee members explained that revenue is obtained from tax and non-tax revenues, revenue from tax is also divided in to two they are direct tax, such as, income tax, property etc... And indirect tax, such as, value added tax which is imposed on persons whose yearly sales of 500,000 birr and above, TOT and excise tax while non-tax revenue are revenue obtained from different services delivered by the municipality, such as, land lease, professional services, however, revenue from tax, specially, levied on hawkers and traders take the largest proportion .Similarly the Inland Revenue office management committee discussion result confirmed it. Therefore, The data obtained from different sources clearly shows that the town administration did not attempt to exhaust its revenue sources both in preparing its annual revenue collection plan as well as collecting the planned amount, as a result of this, the revenue sources of Halaba special woreda the town administration predominantly limited to hawkers and traders tax which in turn limit revenue collection.

Table 4.6: Accounting for revenue collected is done by proper Government Accounting System

\begin{tabular}{|l|c|c|c|}
\hline \multicolumn{1}{|c|}{ Alternatives } & Frequency & Percent & Cumulative Percent \\
\hline Strongly disagree & 2 & 2.5 & 2.5 \\
\hline Disagree & 19 & 23.8 & 26.3 \\
\hline Agree & 40 & 50.0 & 76.3 \\
\hline Strongly agree & 19 & 23.8 & 100.0 \\
\hline Total & 80 & 100.0 & \\
\hline
\end{tabular}


Source: Own survey, March, 2015

\subsubsection{Government Accounting System}

One of the most important components of any revenue collection system is the use of accurate and timely reporting. Local governments need revenue management software that allows revenue collection staff to update records frequently. In this research, respondents were asked to point out whether the collected revenue is accounted in proper government accounting system. As depicted in table 4.6 above, majority of the respondents (combining) $40(50 \%)$ agree and $19(23.8 \%)$ strongly agree $=(73.8 \%)$ think that the collected revenue is accounted in proper government accounting system. On the other hand, 19 (23.8\%) of the respondents and $2(2.5 \%)$ disagree and strongly disagree $=(26.2 \%)$, they think that the revenue collected is not accounted in proper government accounting system. Although the figure is not considered significant the government has done much to execute fiscal policies. The system facilitated ground for transparency and accountability. Hence, It contributed for mitigating factors which has negative impact on revenue collection.

Table 4.7: Which Type of Device do you Use for Identifying and Registering Taxpayers?

\begin{tabular}{|l|c|c|c|}
\hline \multicolumn{1}{|c|}{ Alternatives } & Frequency & Percent & Cumulative Percent \\
\hline Missed & 21 & 26.3 & 26.3 \\
\hline Manual & 25 & 31.3 & 57.5 \\
\hline Automation system & 3 & 3.8 & 61.3 \\
\hline Both of them & 31 & 38.8 & 100.0 \\
\hline Total & 80 & 100.0 & \\
\hline
\end{tabular}

Source: Own survey, March, 2015

\subsubsection{Types of Device for Identifying and Registering Taxpayers}

The device used in registering and identifying taxpayers also affects the amount of revenue to be collected. Technology will give appropriate information for decision making and help to strength internal control system. As depicted in table 4.7 out of 80 respondents 31(38.8\%) replied both, 25(31.8\%) manual and $3(3.8 \%)$ said automation. When the response rate is examined from out of those who agreed or strongly agreed on proper accounting system which is 59, because the question is Restricted to only respondents who agreed and strongly agreed on proper accounting system that is why it is examined out of 59, 31(52\%) said both , 25(42.4\%) manual and only 3 said automation. This shows that more than $50 \%$ of the respondents who agreed or strongly agreed on' accounting for revenue collected is done based on proper government accounting system' think the town administration applies both automation and manual for identification and registration of taxpayers. Partial automation may result mismatch between strategy implementation because there may be significant deviation what the computer expects manually to be done and actually performed. This may result poor control mechanism which leads to ineffective revenue collection.

Table 4.8: Revenue collection is carried out with legal Voucher.

\begin{tabular}{|l|c|c|c|}
\hline \multicolumn{1}{|c|}{ Alternatives } & Frequency & Percent & Cumulative Percent \\
\hline Strongly disagree & 2 & 2.5 & 2.5 \\
\hline Disagree & 2 & 2.5 & 5.0 \\
\hline Agree & 49 & 61.3 & 66.3 \\
\hline Strongly agree & 27 & 33.8 & 100.0 \\
\hline Total & 80 & 100.0 & \\
\hline
\end{tabular}


Source: Own survey, March, 2015

\subsubsection{Revenue Collection is carried out With Legal Vouchers}

Voucher is a document used to prove transactions and it reduces theft as shown in table 4.8, where majority of the respondents (combining) 49(61.3\%) agree and 27(33.8\%) strongly agree. Hence, revenue collection is carried out with legal voucher, but 2(2.5\%) disagree and 2(2.5\%) strongly disagree; this means that only $5 \%$ of the respondents think revenue collection is not carried out with legal vouchers. This implies that there is a voucher system for verifying and approving every transaction which in turn helps for internal control and monitoring in order to take corrective measures when things are done wrongly. It also helps that amount of revenue collected will be utilized for the intended purpose. On the other hand, some respondents in the open-ended questions explained that revenue collection officers collect revenue with and without voucher; this response is also supported by municipality manager interview result and researcher's own observation which contradict the close ended response result.

Table 4.9: Revenue is collected using clear rules, regulations and procedures

\begin{tabular}{|l|c|c|c|}
\hline \multicolumn{1}{|c|}{ Alternatives } & Frequency & Percent & Cumulative Percent \\
\hline Strongly disagree & 9 & 11.3 & 11.3 \\
\hline Disagree & 22 & 27.5 & 38.8 \\
\hline Agree & 38 & 47.5 & 86.3 \\
\hline Strongly agree & 11 & 13.8 & 100.0 \\
\hline Total & 80 & 100.0 & \\
\hline
\end{tabular}

Source: Own survey, March, 2015

\subsubsection{Rules, Regulations and Procedures}

If revenue enforcement procedure is not properly implemented and revenue evaders are not strictly controlled to pay their tax as per the schedule, this may be due to lack of clear guidelines and inadequate management system. In this research, as indicated in 4.9, when respondents were asked about revenue collection rules, regulations and procedure, the majority of them (combining) 38(47.5\%) agree and $11(13.8 \%)$ strongly agree $=49(61.3 \%)$. This shows that the revenue is collected using clear rules, regulation, and procedures. Similarly, combining both respondents (strongly disagree 9(11.3\%) and disagree $22(27.5 \%$ ) or $31(38.7 \%$ ), respondents think that revenue is not collected using clear rules, regulations and procedure. Nevertheless more than $60 \%$ of the respondents agree or strongly agree on the fact that revenue is collected based on clear rules, regulations and procedures. Out it should, we note that nearly half of the respondents think revenue is not collected using clear rules, regulation and procedures. This should have made the government to be conscious and enhance transparency and accountability and collect revenue smoothly from the citizens.

Table 4.10: Complaints is solved timely

\begin{tabular}{|l|c|c|c|}
\hline \multicolumn{1}{|c|}{ Alternatives } & Frequency & Percent & Cumulative Percent \\
\hline Strongly disagree & 6 & 7.5 & 7.5 \\
\hline Disagree & 39 & 48.8 & 56.3 \\
\hline Agree & 27 & 33.8 & 90.0 \\
\hline Strongly agree & 8 & 10.0 & 100.0 \\
\hline Total & 80 & 100.0 & \\
\hline
\end{tabular}


Source: Own survey, March, 2015

\subsubsection{Complaints Handling}

An effective and efficient program of taxpayer service activities is a critical objective of all revenue bodies. It helps for saving cost of revenue collection and will help reducing the gap between the amounts of taxes should be collected and what is actually collected. Awareness and the legitimacy of the tax system have the potential to improve complaints handling. Complaints handling is one of important features of tax services to prove tax compliance so that to increase tax revenue. However, it has been difficult to prove quality tax services among tax experts and is a regular feature of tax reforms Yousu (2012). As depicted in table 4.10 regarding complaints are handled and solved timely, to this end, 45 respondents $(7.5 \%)$ and $(48.8 \%)$ out of 80 replied disagree and strongly disagree, while 35 respondents $(33.8 \%)$ and (10\%) out of 80 said agreed and strongly agreed. Unfortunately, this research points out that compliance is not timely solved. The data presented in table 4.4 therefore, indicates that majority of responses (combining both disagreed and strongly disagreed $=(56 \%)$ think that complaints are not solved timely. This shows that there is compliance handling problem which increase revenue collection cost .On the other hand reduces the number of tax payers who come to the tax net by their own initiates which in turn reduce government revenue.

Table 4.11: Public attitude towards public revenue is positive

\begin{tabular}{|l|c|c|c|}
\hline \multicolumn{1}{|c|}{ Alternatives } & Frequency & Percent & Cumulative Percent \\
\hline Strongly disagree & 8 & 10.0 & 10.0 \\
\hline Disagree & 24 & 30.0 & 40.0 \\
\hline Agree & 38 & 47.5 & 87.5 \\
\hline Strongly agree & 10 & 12.5 & 100.0 \\
\hline Total & 80 & 100.0 & \\
\hline
\end{tabular}

Source: Own survey, March, 2015

\subsubsection{Attitude}

Revenue collection is also impeded by public attitudes towards public revenue (Yousuf, 2012) .If public attitude towards public revenue is positive; it will have positive impact on revenue collection. If attitudes towards public revenue are negative the impact on revenue collection will be negative from the researcher's own observation. Some of the outcomes of this research were surprising and unexpected. For instance, as shown in table 4.11 obtained from the field survey when, employees were asked about public attitude towards public revenue collection, the majority of employees (combining) 38(47.5\%) agree and $10(12.5 \%)$ strongly agree $=48(60 \%)$ which shows that there is positive attitude towards public revenue. The remaining employees (combining) $24(30 \%)$ disagree and $8(10 \%)$ strongly disagree $=32(40 \%)$ ) think that public attitude towards public revenue is negative. For same question as the data presented in taxpayer analysis part, most of taxpayers (combining) 36(56.3\%) agree and 27(42.2\%) strongly agree $=63(91.2 \%)$ ) think that public attitude towards public revenue is positive and only taxpayers $1(1.6 \%)$ strongly disagree think that public attitude towards public revenue is negative. However, in openended questions almost all respondents' suggestion, as well as interview and focus group discussion result shows there are many attitudinal problems, such as, rent seeking, lack of motivation, seemingly arbitrary behavior by revenue officials and lack of transparency, lack of commitment of existing revenue officers to collect public revenue. Even though it is in contrast with the closed- ended question result, most of the respondents in open ended question, all of the interviewed mayor committee members listed down a lot of problems which indicate negative attitude to public revenue which negatively affect revenue collection.

Table 4.12: Salary paid for revenue collection officers are sufficient 


\begin{tabular}{|l|c|c|c|}
\hline \multicolumn{1}{|c|}{ Alternatives } & Frequency & Percent & Cumulative Percent \\
\hline Strongly disagree & 6 & 7.5 & 7.5 \\
\hline Disagree & 18 & 22.5 & 30.0 \\
\hline Agree & 31 & 38.8 & 68.8 \\
\hline Strongly agree & 25 & 31.3 & 100.0 \\
\hline Total & 80 & 100.0 & \\
\hline
\end{tabular}

Source: Own survey, March, 2015

\subsubsection{Salary}

As presented in table 4.12, respondents were asked about the sufficiency of salary paid for revenue collection officers out of 80 employees, $(22.5 \%)$ and $(7.5 \%)$ disagree and strongly disagree think that salary paid for revenue collection officers is not sufficient. On the other hand, $(38.8 \%)$ and $(31.3 \%)$ agree and strongly agree think that salary paid for revenue collection officers are sufficient. This reveals that majority $(80.1 \%)$ of them think that salary paid for revenue collection officer sufficient. As a result of this, there is low turnover which contribute experienced revenue collection officers which in turn promote revenue collection efficiency.

Table 4.13: Revenue bases are accurately assed by collectors

\begin{tabular}{|l|c|c|c|}
\hline \multicolumn{1}{|c|}{ Alternatives } & Frequency & Percent & Cumulative Percent \\
\hline Strongly disagree & 8 & 10.0 & 10.0 \\
\hline Disagree & 37 & 46.3 & 56.3 \\
\hline Agree & 26 & 32.5 & 88.8 \\
\hline Strongly agree & 9 & 11.3 & 100.0 \\
\hline Total & 80 & 100.0 & \\
\hline
\end{tabular}

Source: Own survey, March, 2015

\subsubsection{Revenue Base Assessment}

Revenue can be increased by increasing the revenue base which means including or redefining previously exempted tax. A different choice of assessment methods can increase the assessed value to collect more revenues (Wong, 2006). This is done when the increase in tax rate is not enough to cover the budget gap. This research asked respondents about the accuracy of revenue assessment to which the majority of employee respondents as well as taxpayer respondents think that revenue base is not accurately assessed. As depicted in table 4.13, more than 50\% of employees (37 (46.3\%) disagree and 8(10\%) strongly disagree $=44(56.3 \%)$, they think that revenue bases are not accurately assessed by collectors, whereas, $26(32.5 \%)$ agree, and 9(11.3\%) strongly agree. for the same question, as indicated in the data presented taxpayer analysis part, out of 64 taxpayers $(29(45.3 \%)$ agree and5(7.8\%) strongly agree $=31(53.1 \%)$, think that the authority has identified and registered all taxpayers of the town while $5(7.8 \%)$ disagree,25(39.1\%) strongly disagree think that the authority has not properly identified and registered taxpayers of the Town administration. On average both employees as well as taxpayer's response rate for disagree and strongly disagree is above 50\%.Moreover, open-ended question result of same and interview as well as focus group discussion result shows that there is no accurate assessment of tax which leads to the decrease in the amount of revenue collected. 


\subsubsection{Factors Affecting Revenue Planning}

Table 4.14: Revenue base is determined based on actual need

\begin{tabular}{|l|c|c|c|}
\hline \multicolumn{1}{|c|}{ Alternatives } & Frequency & Percent & Cumulative Percent \\
\hline Strongly disagree & 15 & 18.8 & 18.8 \\
\hline Disagree & 35 & 43.8 & 62.5 \\
\hline Agree & 22 & 27.5 & 90.0 \\
\hline Strongly agree & 8 & 10.0 & 100.0 \\
\hline Total & 80 & 100.0 & \\
\hline
\end{tabular}

Source: Own survey, March, 2015

\subsubsection{Revenue Base Determination}

Revenue base is the event from which revenue is collected. As presented in Table 4.14 above, employees were asked the level of agreement about revenue determined based on actual need, To this end, the majority of employees (combining) $35(43.8 \%)$ disagree and $15(18.8 \%)$ strongly disagree $=50(62.6 \%)$, think that revenue base is not determined based on actual need. In contrast,(combining 22(27.5\%) agree and $8(10 \%)$ strongly agree $=30(38.8 \%)$ think that revenue base is determined based on actual need. As shown in table 4.14 , out of 80 respondents 35(43.8\%) disagree, 22(27.5\%) agree, $15(18.8 \%)$ strongly disagree and $8(10 \%)$ strongly agree. However, the majority $(71.3 \%)$ of the respondents disagrees or strongly disagrees on revenue base being and determined on actual need. This shows that there is a gap between what was collected and what has to be collected.

Table 4.15: Taxpayers register their actual revenue amount

\begin{tabular}{|l|c|c|c|}
\hline \multicolumn{1}{|c|}{ Alternatives } & Frequency & Percent & Cumulative Percent \\
\hline Strongly disagree & 19 & 23.8 & 23.8 \\
\hline Disagree & 47 & 58.8 & 82.5 \\
\hline Agree & 12 & 15.0 & 97.5 \\
\hline Strongly agree & 2 & 2.5 & 100.0 \\
\hline Total & 80 & 100.0 & \\
\hline
\end{tabular}

Source: Own survey, March, 2015

\subsubsection{Registration of Actual Revenue Amount}

The revenue plan also depends on the actual registration of the revenue sources. As indicated in table 4.15 employees were asked about their level of agreement on taxpayers' registration of their actual revenue amount, Majority of employees $47(58.8 \%)$ disagree and $19(23.8 \%)$ strongly disagree $=65(81.3 \%)$ ) that taxpayers register their actual revenue amount while the remaining employees (combining 12(15\%) agree and $2(2.5 \%)$ strongly agree $=15(18.7 \%)$ replied that taxpayers register their actual revenue amount. This revealed that under estimation of revenue capacity which negatively affected revenue planning which in turn decrease the revenue to be collected. 
Table 4.16: A proper forecasting method is employed for estimating revenue

\begin{tabular}{|l|c|c|c|}
\hline \multicolumn{1}{|c|}{ Alternatives } & Frequency & Percent & Cumulative Percent \\
\hline Strongly disagree & 13 & 16.3 & 16.3 \\
\hline Disagree & 33 & 41.3 & 57.5 \\
\hline Agree & 28 & 35.0 & 92.5 \\
\hline Strongly agree & 6 & 7.5 & 100.0 \\
\hline Total & 80 & 100.0 & \\
\hline
\end{tabular}

Source: Own survey, March, 2015

\subsubsection{Forecasting Method}

Forecasting method employed for estimating revenue also affects revenue planning even if the collected information is valid and relevant sometimes inappropriate revenue forecasting method will lead poor planning. The forecasting method employed will also determine the appropriateness of the revenue Plan. As the data presented in table 4.16, employees were asked about the level of agreement on appropriateness of the forecasting method employed for estimating revenue, more than $50 \%$ of employees(combining)33(41.3\%) disagree and 13(16.3\%) strongly disagree $=46(57.5 \%)$ ) think that proper forecasting method is not employed for estimating revenue, (combining 28(35\%) agree and 6(7.5\%) strongly agree $=34(43 \%)$ think that proper forecasting method is employed for estimating revenue. This shows that the method employed by the Town administration for estimating revenue contributed to poor revenue planning.

Table 4.17: What are the forecasting mechanisms adopted in your office?

\begin{tabular}{|l|c|c|c|}
\hline \multicolumn{1}{|c|}{ Alternatives } & Frequency & Percent & Cumulative Percent \\
\hline Missed & 48 & 60.0 & 60.0 \\
\hline Systematic evidence & 26 & 32.5 & 92.5 \\
\hline Assumption criteria & 6 & 7.5 & 100.0 \\
\hline Total & 80 & 100.0 & \\
\hline
\end{tabular}

Source: Own survey, March, 2015

\subsubsection{The Forecasting Mechanisms Employed}

As indicated in table 4.17 above, employees were asked about the forecasting mechanisms adapted in their office, to this end, out of 80 employees, 26(32.5\%) systematic evidence, 6(7.5\%) assumption criteria. On the other hand, combining (41.3\%) disagreed and (16.3\%) strongly disagreed on question 4.16 are not liable to question 4.17 and $2(2.5 \%)$ wrong option $=48(60 \%)$ are considered as missed. From this we can understand the fact that even though $32.5 \%$ replied that as the forecasting type as systematic evidence, it is difficult to judge based on $32.5 \%$ rather it is easier to conclude that the Town administration did not employed proper forecasting method .Moreover it implies that inappropriate forecasting method negatively affected revenue planning which in turn hindered revenue management objectives of Halaba special woreda Town administration. 


\subsubsection{The Roles of Management Tools and Techniques in Revenue Mobilization}

Management tools and techniques play a major role in revenue mobilization. The management tools and technologies should have to allow policy of transparent recruitment, sufficient remuneration, pension schemes accompanied by a policy of attracting, retaining and motivating based on qualification and performance (Swanson, 2001).

Table 4.18: Qualified Employees are hired for Revenue Collection

\begin{tabular}{|l|c|c|c|}
\hline \multicolumn{1}{|c|}{ Alternatives } & Frequency & Percent & Cumulative Percent \\
\hline Strongly disagree & 7 & 8.8 & 8.8 \\
\hline Disagree & 23 & 28.8 & 37.5 \\
\hline Agree & 41 & 51.3 & 88.8 \\
\hline Strongly agree & 9 & 11.3 & 100.0 \\
\hline Total & 80 & 100.0 & \\
\hline
\end{tabular}

Source: Own survey, March, 2015

\subsubsection{Qualified Employees}

As depicted in the table 4.18 above ,employees were asked to know whether qualified employees are hired for revenue collection, To this end, the majority of employees(combining) 41(51.3\%) agree and $9(11.3 \%)$ strongly agree $=50(62.6 \%)$ think that qualified employees a rehired. In contrast (combining) $23(28.8 \%)$ disagree and $7(8.8 \%)$ strongly disagree $=30(37.5 \%)$ replied that qualified employees are not hired. Similarly interview and focus group discussion result shows there is, lack of required skill for revenue officer which hinder revenue management objective through increasing cost of revenue management, such as, cost of training, cost of making error and cost of time.

Table 4.19: There is Different Type of Reward System in Order to Motivate Employees Based on Their Performance

\begin{tabular}{|l|c|c|c|}
\hline \multicolumn{1}{|c|}{ Alternatives } & Frequency & Percent & Cumulative Percent \\
\hline Strongly disagree & 10 & 12.5 & 12.5 \\
\hline Disagree & 41 & 51.3 & 63.8 \\
\hline Agree & 20 & 25.0 & 88.8 \\
\hline Strongly agree & 9 & 11.3 & 100.0 \\
\hline Total & 80 & 100.0 & \\
\hline
\end{tabular}

Source: Own survey, March, 2015

\subsubsection{Reward System}

If there is reward system and clear and defined procedures of revenue mobilization, employees will be motivated to perform according to the procedures. Because if employee are treated fairly and they are rewarded their better performance, they feel sense of ownership and responsibility and perform activities accordingly (Swanson et al, 2001).In this research they were asked about the level of agreement on the existence of reward system which motivate employees based on their performance, as shown in table 4.19 above, To this end, the majority of employees( combining) $41(51.3 \%)$ disagree and $10(12.5 \%)$ strongly disagree $=51(63.8 \%)$ think that there are no reward system which motivate employees based on their performance. While, (combining) 20(25\%) agree and 9(11.3\%) strongly agree $=29(36.3 \%)$ replied that there are different types of reward system which motivate employees based on their performance. This shows that there is a lack of motivation which makes employees to perform below their actual performance which in turn will hamper revenue management objective. 
Table 4.20: The level of contribution attributed by the reward system

\begin{tabular}{|l|c|c|c|}
\hline \multicolumn{1}{|c|}{ Alternatives } & Frequency & Percent & Cumulative Percent \\
\hline Missing & 51 & 61.3 & 61.3 \\
\hline Fairly & 4 & 5.0 & 66.3 \\
\hline Good & 7 & 8.8 & 75.0 \\
\hline Very good & 14 & 17.5 & 92.5 \\
\hline Excellent & 4 & 5 & 100.0 \\
\hline Total & 80 & 100.0 & \\
\hline
\end{tabular}

Source: Own survey, March, 2015

\subsubsection{Level of Contribution of Reward System}

As shown in the table 4.20 above, out of 80 respondents, 51 (61.3\%) are treated as missed because this question is restricted to those who agreed or strongly agreed on the existence of different reward system which motivate employees based on their performance. Those who believed on the existence of reward system, were asked the level of contribution attributed by it as additional question, out of it should, replied 14(17.5\%) very good, 7(8.8\% ) good, 4(5\%) excellent and 4(5\%)fairly. This reveals that Halaba special woreda Town administration did not designed reward system to motivate employees based on their performance this in turn negatively affected revenue management objectives.

\subsubsection{Analysis of Response Rate of Taxpayers:}

Table 4.21: To what extent you agree that government is trust worthy to collect revenue from its citizens?

\begin{tabular}{|l|c|c|c|}
\hline \multicolumn{1}{|c|}{ Alternatives } & Frequency & Percent & Cumulative percent \\
\hline & & & \\
\hline Strongly disagree & 1 & 1.6 & 1.6 \\
\hline Agree & 36 & 56.3 & 57.8 \\
\hline Strongly agree & 27 & 42.2 & 100 \\
\hline Total & 64 & 100 & \\
\hline
\end{tabular}

Source: Own survey, March, 2015

\subsubsection{Trust worthiness of the Government}

As depicted in table 4.21above, taxpayers are asked their level of agreement about the trust worthiness of government, almost all taxpayers (combining) 36(56.3\%) agree and 27(42.2\%) strongly agree $=63(98.4 \%$ ) think that government is trust worthy to collect revenue from its citizens while only 1(1.6\%) replied that the government is not trust worthy to collect revenue from its citizens. This outcome should have made it easier for the government to collect revenue smoothly from the taxpayers, yet as the research Discovered later on that there are other variables that prevent taxpayers from paying their taxes voluntarily. 
Table 4.22: To what extent you agree that the taxes you pay are fairly assessed?

\begin{tabular}{|l|c|c|c|}
\hline \multicolumn{1}{|c|}{ Alternatives } & Frequency & Percent & Cumulative Percent \\
\hline Strongly disagree & 2 & 3.1 & 3.1 \\
\hline Disagree & 20 & 31.3 & 34.4 \\
\hline Agree & 29 & 45.3 & 79.7 \\
\hline Strongly agree & 13 & 20.3 & 100.0 \\
\hline Total & 64 & 100.0 & \\
\hline
\end{tabular}

Source: Own survey, March, 2015

\subsubsection{Fairness of Tax Assessment}

Fair assessment of tax refers the Application of ability to pay and benefits principle which in turn affects the amount of revenue collected. In this research taxpayers were asked to know the level their agreement on the fairness of tax assessment, To this end, more than 60\% of taxpayers (combining) 29(45.3\%) agree and $13(20.3 \%)$ strongly agree $=42(65.5 \%)$ ) think that the tax they pay are fairly assessed .However (combining) 31.3\% disagree and 3.1\% strongly disagree) replied that the tax they pay are not fairly assessed. This result contradicted with the closed-ended question result and interview result of mayor commit members as well as focus group discussion result of Inland revenue office management committee. This shows that there is difference between point of view what mean fair assessment for the Town administration and to taxpayers or tax payers did not want to disclose the problem ,Otherwise, the result of both party would match, However, it is more reliable to conclude based on the data obtained from different source, such as ,mayor committee members, Inland revenue office management committee and employees. Therefore there is no fair assessment of tax which negatively affected revenue collection of the Town administration.

Table 4.23: To what extent do you agree that the authority properly identifies and registers all taxpayers of the town?

\begin{tabular}{|l|c|c|c|}
\hline \multicolumn{1}{|c|}{ Alternatives } & Frequency & Percent & Cumulative Percent \\
\hline Strongly disagree & 5 & 7.8 & 7.8 \\
\hline Disagree & 25 & 39.1 & 46.9 \\
\hline Agree & 29 & 45.3 & 92.2 \\
\hline Strongly agree & 5 & 7.8 & 100.0 \\
\hline Total & 64 & 100.0 & \\
\hline
\end{tabular}

Source: Own survey; March, 2015

\subsubsection{Identification and Registration of Taxpayers}

As indicated the data presented in table 4.23 above, taxpayers were asked their level of agreement on the identification and registration of taxpayers of the town, more than $50 \%$ of taxpayers (combining) $29(45.3 \%)$ agree and $7.8 \%$ strongly agree $=53 \%$ ) think that the authority has identified and registered all taxpayers of the town, On the other hand, (combining) 25(39.1\%) disagree and 5(7.8\%) strongly disagree $=30(46.9 \%)$ think that the authority has not properly identified and registered tax payers of the town administration. Out it should nearly half of the respondents noted that the authority properly identifies and registers all taxpayers of the Town. This should have made the government to be conscious and promote exhaustive identification and registration of taxpayers and achieve revenue collection effectiveness. 
Table 4.24: How do you come to the tax net?

\begin{tabular}{|l|c|c|c|}
\hline \multicolumn{1}{|c|}{ Alternatives } & Frequency & Percent & Cumulative Percent \\
\hline Own initiative & 37 & 57.8 & 57.8 \\
\hline Advertisement & 23 & 35.9 & 93.8 \\
\hline Enforcement & 4 & 6.3 & 100.0 \\
\hline Total & 64 & 100.0 & \\
\hline
\end{tabular}

Source: Own survey, March, 2015

\subsubsection{Tax net}

As indicated the data presented in table 4.24 above, out of 64 respondents, $57.8 \%$ of taxpayers replied by own initiative, $35.9 \%$ by advertisement, $6.3 \%$ by enforcement. This shows that taxpayers have good awareness about tax responsibility which enhance revenue collection efficiency.

Table 4.25: Which types of tax are you levied?

\begin{tabular}{|l|c|c|c|}
\hline \multicolumn{1}{|c|}{ Alternatives } & Frequency & Percent & Cumulative Percent \\
\hline Property tax & 9 & 14.1 & 14.1 \\
\hline Hawkers and traders tax & 51 & 79.7 & 93.8 \\
\hline Ownership transfers & 1 & 1.6 & 95.3 \\
\hline Specify if any other & 3 & 4.7 & 100.0 \\
\hline Total & 64 & 100.0 & \\
\hline
\end{tabular}

Source: Own survey, March, 2015

\subsubsection{Types of tax}

As can be seen from table 4.25 presented above, out of 64 respondents,9(14.1\%) levy property tax,51(79.7\%) levy hawkers and traders tax,1(1.6\%) levy ownership transfer and 3(4.7\%) any other replied. This show that majority of taxpayers registered in the tax net of the Town administration were Hawkers and trader. Whereas, most taxpayers of other taxes were not registered in the database of the organization. This clearly indicates the Town administration predominantly dependent on Hawkers and traders tax to its revenue which limits exhaustive exploitation of other taxes which in turn have a negative impact on revenue collection.

Table 4.26: When do you pay tax?

\begin{tabular}{|l|c|c|c|}
\hline \multicolumn{1}{|c|}{ Alternatives } & Frequency & Percent & Cumulative Percent \\
\hline On time & 59 & 92.2 & 92.2 \\
\hline With a penalty & 5 & 7.8 & 100.0 \\
\hline Total & 64 & 100.0 & \\
\hline
\end{tabular}

Source: Own survey, March, 2015

\subsubsection{Time of tax payment}

As indicated in table 4.26 above, taxpayers were asked when they pay tax, most $(92.2 \%)$ of them told that they pay on time .However, only $7.8 \%$ think that they pay with penalty. This shows that most of taxpayers discharge their responsibility on time which have made easier for the government to collect revenue at lower cost. 
Table 4.27: Do you think that there is sufficient and committed human power in the office?

\begin{tabular}{|l|c|c|c|}
\hline \multicolumn{1}{|c|}{ Alternatives } & Frequency & Percent & Cumulative Percent \\
\hline Yes & 41 & 64.1 & 64.1 \\
\hline No & 23 & 35.9 & 100.0 \\
\hline Total & 64 & 100.0 & \\
\hline
\end{tabular}

Source: Own survey, March, 2015

\subsubsection{Existence of Sufficient and commitment of human power}

As shown the data presented in table 4.27 above, taxpayers were asked about what they think about there is sufficient and committed human power in the office. To this end, majority of taxpayers $(64.1 \%)$ they think that there is sufficient and committed human power in the office. In contrast, $35.9 \%$ of them think that there is no sufficient and committed human power in the office. This revealed that there is sufficient and committed human power in the Town administration which has positive impact on revenue management objective.

Table 4.28: Do you face any problem when you pay tax?

\begin{tabular}{|l|c|c|c|}
\hline \multicolumn{1}{|c|}{ Alternatives } & Frequency & Percent & Cumulative Percent \\
\hline Yes & 23 & 35.9 & 51.6 \\
\hline No & 40 & 62.5 & 98.4 \\
\hline Total & 63 & 98.4 & 100 \\
\hline Missing & 1 & 1.6 & \\
\hline & & & \\
\hline
\end{tabular}

Source: Own survey, March, 2015

\subsubsection{Any problem taxpayers face}

As shown the data presented in table 4.28 above, Taxpayers were asked about If they face any problem on the time of tax payment, To this end,23(35.9\%) taxpayers Out of 64 replied that they had faced a problem, However,40(62.5\%) replied that they did not face any problem. This shows majority of the respondents do not face any problem when they come to pay tax this will help for the achievement of revenue management objective.

Table 4.29: Do you believe that the work of illegal traders and non-registered taxpayers has an impact on your attitude towards tax?

\begin{tabular}{|c|c|c|c|c|}
\hline & Frequency & Percent & Valid Percent & Cumulative Percent \\
\hline Yes & 64 & 100.0 & 100.0 & 100.0 \\
\hline
\end{tabular}

Source: Own survey, March, 2015

\subsubsection{Illegal Traders and non-Registered Taxpayers}

As shown the data presented table 4.29 above, taxpayers were asked about the believe that they have on the work of illegal traders and non-registered taxpayers have an impact on your attitude towards tax, All respondents $(100 \%)$ told that replied it has an impact on their attitude towards tax. This shows that there is equal awareness among all taxpayers regarding impact of illegal traders and non-registered taxpayers on their attitude towards tax. Furthermore, they justified their argument with an open ended question "how? Please explain" They explained that as is known that the reason why they opt to be illegal and 
non-registered is to enjoy at the expense of public revenue and develop in a shorter time without adding value to the nation, they also use as an strategy to withdraw their competitors from the market by lowering price at the expense of tax. It increases the cost of the business which leads to the rise in price of goods and services provided by taxpayer, as a result of this, those who pay tax and who do not pay tax could not compete in the same market either to withdraw from the market or to be engaged in illegal trading and made their maximum effort to non-register their business'. This shows that it has a negative impact on legal traders and registered taxpayers leading to them to have negative attitude towards tax. Finally, taxpayers were asked an open ended question 'What do you suggest for the overall improvement of revenue collection of the town administration'. they suggested a lot of ideas ,however for the purpose of this research they are presented in summarized way as follows, first and for most the town administration should have to respect revenue laws and regulation and protect this laws and regulations not to be violated by others, they should have to treat all taxpayers equally laws should not be used as an instrument to penalize one and reward another without any reason, for instance, if the town administration tolerate, illegal traders and non-registered taxpayers it is just rewarding them and penalizing those who comply laws and regulations, design continuous awareness creation program to internalize the need for public revenue, for instance, we ask the government to construct infrastructure, provide different types of social services, social security. etc., on one hand, we lack commitment to discharge a minimum responsibility on the other hand, this contradicting ideas should have to be reconciled through awareness creation, develop sense of patriotism, take corrective action on those who violate rules and regulations

\subsection{5: Analysis of interview and Focus group Discussion Result}

When interviewees were asked about the major sources of revenue for the town administration, they replied revenue is obtained from tax and non-tax revenues sources. Revenue tax is also divided into two; they are direct tax such as income tax, property tax etc. And indirect tax, such as, VAT, TOT and excise tax. Non-tax revenues are revenue obtained from different services delivered by the municipality such as from land lease, professional services. This showed that even though the result from the questionnaires indicated the major sources of the town administration are hawkers and traders tax, the interview result was an extension (similar) of it and what they added were non tax revenues. Furthermore, the focus group discussion result strengthened it. For same question, the focus group discussion members explained that even though the government allocates a certain amount of grant, the major revenue sources of the town administration is hawkers and traders tax imposed on individuals who earn monthly income of above 1800birr, value added tax which is imposed on yearly sales of 500,000 and the other source is municipality revenue. This revenue is collected from different types of services delivered to the town, however they told that above $50 \%$ of revenue comes from hawkers and traders. Therefore, hawkers and traders tax can be considered as the major revenue sources of the town administration. As a result of this, hawkers and traders tax, is not if not properly administered, significantly affect the amount of revenue collected by the town administration.

When asked about the trends of revenue growth for the last three years, it was fact that there is a progress. However, when it is compared with the plan there is large deviation. As presented in the figure below from 2004_2006.E.C.

\subsubsection{Revenue collection trends from 2004-2006(E.C)}

\begin{tabular}{|l|c|c|c|}
\hline \multicolumn{1}{|c|}{ Year (E.C) } & $\mathbf{2 0 0 4}$ & $\mathbf{2 0 0 5}$ & $\mathbf{2 0 0 6}$ \\
\hline Planned revenue & $8,000,000$ & $17,600,000$ & $20,000,000$ \\
\hline Collected revenue & $7,604,720$ & $13,008,668$ & $15,819,560$ \\
\hline
\end{tabular}


Figure 4.1: Revenue collection trend diagram.

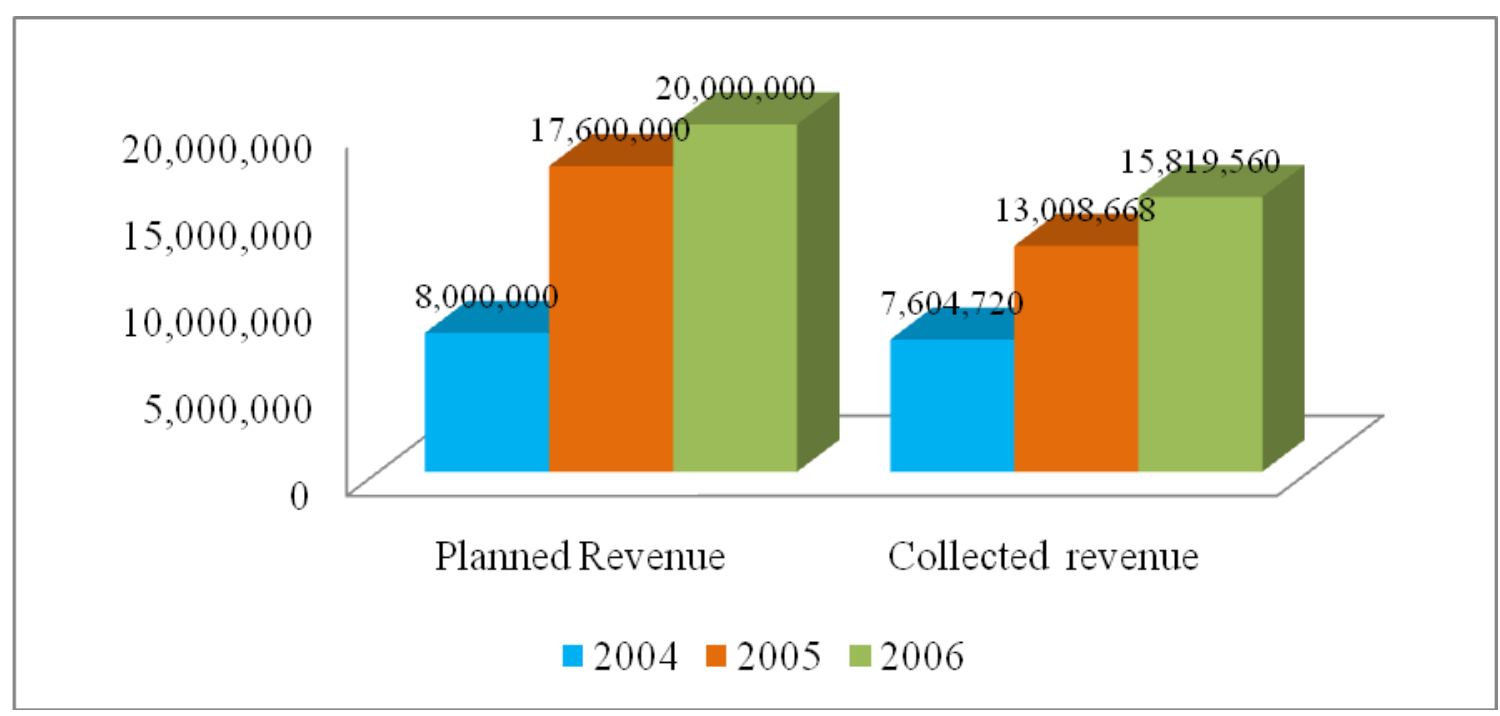

Source: Own survey, March, 2015

This revealed that the Town administration unable to solve the problem. As a result of this, the deviation continued for the last three consecutive years. Discussants also listed a lot of reasons for not collecting the planned amount of revenue, such as, ambitious plan which lacks consideration of the existing condition, such as ;

- Lack of institutional capacity

- lack of qualified man power and lack of motivation

- Lack of commitment of revenue officers

When discussants were asked about what factors affect revenue management, the entire interviewees and discussants responded that the factors affecting revenue management is divided into two. Internally, within the town administration, such as lack of required skill, inefficient manpower and attitudinal problems externally, lack of public awareness, rent seeking behavior of taxpayers. The focus group discussion members were asked "what are the factors that affect revenue management in the town administration?" 'They enumerated the factors affecting revenue management, as follows;

- poor planning

- Lack of institutional capacity.

- absence of reward system

- lack of technology

- lack of full implementation of revenue rules and regulation

- Lack of commitment of revenue officers and attitudinal problems of taxpayers are considered as major factors affecting revenue management.

When discussants were asked on the methods and procedures employed for assessing and collecting revenue, they responded that taxpayers who are categorized under level " $\mathrm{A}$ " and " $\mathrm{B}$ " prepare their account records and submit to revenue office. Based on that, the amount of tax is determined and collected, while for taxpayer who is categorized under level " $\mathrm{C}$ " the revision is made every three years by establishing an ad hoc committee which involves different stake holders, taxpayers and experts from revenue office. Furthermore, the focus group discussion result revealed the same with that of the interview .Regarding salary of revenue officers, all the discussed public officials said that salary paid for revenue officers sufficient and relative to the current development level of the country, They are even 
well paid when compared with other sectors. Similarly focus group discussion result justified it by presenting the argument in such a way that revenue office has their own salary structure designed in regional state. It has been put into effect to allow paying salary better than from other public sector, because of improvement of salary level, new graduates inquire to be recruited in revenue office. This shows that salary payment has positive impact on revenue collection. Concerning fairness of tax imposition, most of the discussants result showed there is fair imposition of tax. Moreover, there is an appeal system to investigate the cause for unfairness. However, there is gap in giving immediate solution. Whereas, focus group discussion result revealed that the tax imposed on them is not as such a big deal rather fairness is dealt with illegal tax discounts and exemptions which has a big impact on their business to the worst which leads them to withdraw. This is specially accompanied with TOT and VAT. Recognizing this town administration has been taking corrective measures. Regarding revenue base, the result of the discussion shows, most of them replied as it depends on the quality of data employed to determine tax they also told that as it is difficult to think proper decision without having well established database management. Whereas focus group discussion result informed that it has its own core processes which work on identification of the potential revenue sources. It organizes information and submits to the council of the town administration and the council discuses and determine on revenue. On the subject of fair treatment of taxpayers the discussion result showed 50\% thought that there is fair treatment. However $50 \%$ of them thought that there is no fair treatment which is convoyed with attitudinal problems of revenue officers and lack of discipline. similarly, focus group discussion result revealed as there is fair treatment of taxpayers as far as rules and regulations are concerned, however that does not mean there is no unfair treatment .even though the unfairness not favoring the government revenue, rather it arises , as result of unnecessary relationship that will favor both collectors and taxpayers at the expense of the government revenue, since the need to address this issue is not the responsibility of the government but also require collaboration of taxpayer .Regarding rules and regulation most of the discussant thought that revenue collection is done based on government rules and regulations .However, it is difficult to say full implementation due to different reasons there is occasions in which rules and regulations are manipulated by revenue experts as well as by taxpayers for their mutual benefit at the expense of government revenue. Moreover, focus group discussion result is in line with the interview it also showed that there is lack of efficient implementation of rules and regulations which in turn negatively affected revenue management efficiency. The discussant were asked about the control mechanism and procedures applied for revenue management, three of them replied that mainly focus on reports, Revenue officers also undertake door to door control. In addition to that, "the municipality manager told that they use 1 to 5 change army group as a tool for control mechanism each team member will enforce each other to discharge their Responsibilities and the better performer change army group will be rewarded". Similarly, focus group discussion result showed that revenue management control mechanism, mainly focus on report to take corrective measure on identified weakness in the report and capitalize strengths. Regarding management mechanism employed to improve revenue management efficiency, municipality manager told that it was one of the sectors in which BPR has been implemented in order to improve revenue management. However, it did not brought the desired level of improvement because of lack of technology, lack of required skill and attitudinal problems. Focus group discussion result showed that as they have done a lot on training employees, especially revenue collection officers at town administration level and regional state level, they have created awareness using different meetings for the general public, specially, for business society. However, it did not contributed a lot for revenue management efficiency. As a result of this they told that as they have planned to give training based on need assessment, established committees for regular supervision and intelligence work of business activities.

\subsection{Discussions and Findings}

As discussed from the very beginning of this research, Public sector revenue management is the sub set of financial management which focuses on revenue generating and spending for various development programs designed to achieve organizational goals. The importance of public sector revenue management could not be exaggerated since taking this insight into consideration this research has attempted to assess 
factors that affect public sector revenue management in the case of Halaba special woreda town administration. On the basis of data analysis part the following discussions are carried out.

\subsubsection{Discussions on Factors Affecting Revenue Collection}

According to the data obtained from the field work, it clearly shows that the town administration did not attempt to exhaust its revenue sources when it prepares its annual revenue collection plan. As the data obtained show, the revenue sources of the town administration predominantly, dependent on hawkers and traders tax .It accounted for the greatest amount of the total revenue compared with other types of taxes as well as revenue from non-tax sources. According to Shah (2007, p34,)Local governments collect funds from a variety of revenue sources, including fines, fees, taxes, licenses, permits, and special assessments. In contrast Halaba special woreda Town administration depend more on hawkers and trader's tax for its revenue sources .Moreover, the data revealed other taxes as well as non-tax source were not exhaustively exploited. It gives an insight that the Town administration neither properly administered hawkers and traders tax nor exhaustively exploited other sources. As a result, they negatively affected the amount of revenue collected by the town administration. In other words, the performance of the mentioned revenue sources had a greater impact on revenue generation.

Regarding revenue accounting, according to ERCA (2008) cited by Mukhtar, it involves timely recording of collection, recording payments to individual taxpayers' fills to appropriate accounts, report and review the accuracy of regulatory information and it also facilitates refunds, bank reconciliation and sharing revenue between different levels of governments. According to the data presented in table 4.6, relatively shows the collected revenue could not be misused by collectors and facilitates favorable environment to enhance accountability and transparency which in turn contributes to revenue collection efficiency and refunding of Revenue for the intended purpose. Furthermore, this outcome should have created a fertile ground for the government to execute fiscal policies by contributing revenue management efficiency.

About the types of device used for identifying and registering taxpayers, The data presented in table 4.7, clearly depicts they were not convenient in taxpayer identification and registration, taxpayers are known identification and registration is a foundation for other tax administration tasks, according to (Bird and zolt,2004), it should establish a system to register non voluntarily taxpayers. Furthermore, taxpayer's identification and registration helps to find out potential taxpayers for tax objectives, and registering them as taxpayers in a central data base. The mechanism employed by Halaba special woreda town administration was not fully automated which has made impossible to handle data in a central data base. As a result of this, the town's administration has not been benefiting from the fruits of full automation.

With regard to the legal voucher, as indicated the data presented in table 4.8, even though the result of closed- ended responses revealed revenue collection has been carried out with legal voucher, the response of open- ended questions and researcher's own observation shows mixed type of collection means with and without voucher. This could be the outcome of lack of automation which paralyzed government revenue.

Vis-à-vis rule, regulations and procedures as the data obtained in field survey having the trust of more than $60 \%$ of the respondents indicated revenue collection is based on rules, regulations and procedures. However, losing the trust of more than $35 \%$ of the respondents clearly indicates that there was gap in collecting revenue based on rules, regulations and procedures. This could also be the result of lack of use of technology which could be attributed to the misuse of Halaba special woreda town administration revenue.

On the topic of Complaints handling, awareness and the legitimacy of the tax system, they have the potential of improving complaints handling system (Yuosuf, 2012). Unfortunately, this research pointed out that complaints are not timely solved which clearly indicated the cost of revenue collection to be high which decreased Halaba special woreda town administration's revenue. 
Concerning Attitude, according to Aaron (2004) evasion involves more than cost benefit calculation and reflects the taxpayer's sense of duty, perception of the fairness of the tax system, and trust in government and the political system more broadly. Even though the majority of both taxpayer respondents and employee response for close -ended is in line with the literature, but almost all respondents response for the open ended question and focus group discussion results revealed there is a negative attitude towards public revenue. It was also supported by researcher's own observation during data collection stay in Halaba special woreda I visited 6 VAT registered restaurants and clothing shops and none of the taxpayers (business persons) gave receipt to customers and none of the customers asked for receipt, the other observation was that some Hotels use hand written receipts and it takes a lot of time to serve all costumers. As a result, it requires patience and commitment of both. This clearly revealed that the town administration has carried out training and awareness creation. It has a limitation for identifying gaps which impacted on reduction of revenue collected.

Revenue Base; According to Tanzi (2003), peoples tax payment should be in line with their income and they are required to pay a tax in proportion to their level of income. On the other hand tax collectors and etc. must guide by the principle that, collection of revenue should be time conscious and convenient and the cost of collecting taxes should not be high to discourage the business. Unfortunately, this research revealed that town administration has not exhaustively exploited the revenue potential of the town. The reason for this is poor assessment of taxable sources, reliance only on hawkers and traders tax. These two instances could be considered as indicator for the low revenue in Halaba special woreda town administration.

\subsubsection{Discussions on Factors Taken in to Consideration for Revenue Planning}

Concerning revenue base determination, the data presented in table 4.14 shows the town administration did not carried out need assessment in order to determine actual need that should be incorporated in revenue planning. As a result, it negatively affected revenue management. Similarly, interview and focus group discussion result affirmed. Moreover, it is difficult to determine actual need without having proper data base management system .As a result; it negatively affected revenue planning which in turn affected revenue management objectives.

With regard to registration of actual revenue amount, as is known the revenue plan also depends on the actual registration of the revenue amount. If the designed plan is not based on actually registered revenue amount which in turn affect revenue management. According to the data presented in table 4.23 of taxpayer analysis and table 4.16 of the employee's analysis part, it can be understood that taxpayer response result for same question showed there is a gap in registration of actual revenue amount. In addition to that, majority of the employees response result for opened-ended questions revealed that tax payers did not register their actual revenue amount which negatively affected revenue planning attributing for poor revenue management of the town administration.

As regards revenue Forecasting method, it also affects revenue planning .Even if the collected information is valid and relevant, sometimes inappropriate revenue forecasting method will lead poor planning. The data presented in table4.17 clearly shows the town administration did not employ proper forecasting method which negatively affected revenue planning. In addition the forecasting mechanism adopted by town administration affected revenue planning it relies on assumption rather than systematic evidence.

\section{Role of Management Tools and Techniques to Revenue Management}

The data presented in table 4.18 revealed that qualified employees are recruited. However, Absence of reward system to motivate employees based on their performance they are not contributing to revenue management efficiency, similarly interview and focus group discussion result revealed the same. Moreover, focus group discussion result also added the following reasons, such as, lack of required skill, 
rent seeking behavior of revenue officers, absence of integrated revenue management approach .As a result of these, The role of management tools and techniques 'contribution to revenue management is insignificant.

From the data presented in taxpayer analysis part it can clearly showed that taxpayers are well aware about the importance of public revenue which should made easier for the government to collect tax from its citizens, regarding fairness of tax, the data presented in taxpayer analysis part revealed that the tax they pay were fair this also have a positive contribution for revenue collection. Regarding taxpayer identification and registration, 53\% of the taxpayers were agreed on proper taxpayer identification and registration, while $47 \%$ were not agreed and more than $80 \%$ of opened- ended response result for same question showed that there is gap in identification and registration of taxpayers the town. Regarding taxpayers coming to the tax net revealed that they come by their own initiative this could also indicate taxpayers' believe about the trust worthiness of the government to tax its citizens. About timely payment question, the data presented in table 4.26 result showed good sense of discharging their national responsibility which contributes for revenue management objective.

Regarding the existence of sufficient and committed man power, the data presented in the taxpayer analysis part revealed that there is a sufficient and committed man power in the town administration, however when they were asked about whether they face any problem when they come to pay tax they listed many problems even some of the problems were attributed by lack of committed and sufficient human power which increased cost of collection. Concerning illegal traders and non-registered tax payers, the data presented in table 4.29 revealed absolute negative impact on taxpayer attitude towards public revenue which negatively affected revenue collection.

\section{CHAPTER FIVE}

\section{Summary of the Findings, Conclusion and Recommendation}

\section{Introduction}

In chapter four the analysis and discussion of the study was presented. This chapter presents the conclusions and recommendations in line with the findings of the study. The chapter is organized in to two sections .the first section deals with summery and conclusions whereas the second section presents some recommendations suggested as a solution to the problems that have been identified in the study.

To begin with, the main objective of the study was assessing factors that affect public sector revenue management in the case of Halaba special woreda town administration. To conduct the study, both primary and secondary data sources were used. The primary data was collected through questionnaires, interview, focus group discussion and observation; the data was then analyzed using both quantitative and qualitative method. Based on the analysis and discussion part, the following conclusions and recommendations are summarized below.

\subsection{Summary of Findings}

The study of this research has revealed that there are a number of factors that affect revenue management .The factors which affect revenue management can be attributed partly to taxpayers, partly to revenue assessment staff and partly to the authorities.

Based on the objectives of the study, the following major findings are drawn:

a) Even though there are a number of revenue bases that can serve as source of revenue in Halaba special woreda town administration, it mainly relied on hawkers and traders tax. This is because they are identified and registered taxpayers and their lists are available in revenue office, hence, it is easier to collect revenue from them unless intentionally favored.

b) The study revealed that the town administration accounts the collected revenue in proper government accounting system. 
c) Even though the results of close ended question results show the town administration carries out transactions with legal voucher, many respondents for open ended question believed that there are also transactions that are carried out without voucher. This could be the result of attitudinal problems, such as, rent seeking, arbitrary behavior of revenue officers.

d) Even though revenue is collected based on rules, regulations and procedures, it is not comprehensive because it only regulates the behavior of taxpayers who are identified and registered in revenue office and there are also occasions in which rules and regulations are violated.

e) The study revealed that there is a complaint handling problem which encourage tax fraud and increase non registered taxpayers and illegal traders.

f) It was found that one of the factors that affected revenue management was poor planning which was attributed by inaccurate information and improper forecasting method employed by the town administration. In addition to that, the town administration did not put in place proper device for identification and registration of tax payers so as to bring illegal traders and non-registered taxpayers to the tax net. Furthermore, the study also indicated that the town administration lacks computerized revenue management system.

g) The study also found that town administration lacks proper management tools and technique to enhance positive factors that affect revenue management and to mitigate factors that affect revenue management negatively. Moreover, it revealed that the town administration did not design integrated revenue management system for establishing revenue performance standards, documenting revenue performance, comparing actual with expected performance, initiating corrective action and designing controlling mechanisms which would otherwise enabled it for leveraging the commitment of all concerned parties in general, revenue officers and taxpayers in particular. Indicators for these are; lack of sufficient and skilled human power, lack of commitment and motivation of revenue officers and arbitrary behavior of taxpayers.

\subsection{Conclusion}

Halaba special woreda town administration, like other town administration in Ethiopia is expected to provide basic economic and social services to the citizens under its jurisdiction. Despite the fact that revenue sources have been identified, each of the revenue sources is not assessed and taxed carefully. Have not been assessed some revenue sources which negatively affected the revenue management of the town administration. Moreover, poor planning and inefficient managerial system have negatively affected the town administration revenue management. The projecting revenue sources for the town administration are land rent, tax and charge for the provision of technical and related services.

The revenue planned (2004-2006) was birr 45.6 million and 36.3million birr (79\%) has been collected. The gap between planned and actual collection clearly indicates that the town administration was not efficient in its revenue collection performance. Besides, poor assessment of some revenue sources which has not included in the plan proved that the town administration is not effective in revenue collection. The main reasons for this underperformance include lack of trained manpower, inadequate planning, lack of commitment, and poor implementation of revenue collection rules, regulation and procedure, lack of awareness by taxpayers and poor method of data base management.

To sum up, poor assessment of revenue base, lack of full automation, poor implementation of revenue rules, regulations and procedure, poor planning and lack of data base management, lack of awareness in taxpayers, attitudinal problems and lack of commitment of revenue officers are the main findings of this research analysis. These factors collectively affected revenue management of Halaba special woreda town administration through lowering revenue collection performance from expected amount which is revenue planned from (2004-2006) was birr 45.6 million and 36.3 million birr (79\%) has been collected, 
increasing relines on Hawakers and traders tax which is attributed by poor assessment and inaccurate information and low contribution of management tools and techniques to revenue management efficiency.

\subsection{Recommendations}

To enhance the revenue management of Halaba special woreda town administration, the following recommendations could be used as input in the decisions of the concerned bodies:

\section{Widening the town's revenue sources base}

Budget scarcity of the town administration is due to low level of revenue collection. This low level of revenue collection is also the result of weakness in assessing the revenue bases, finding new base and exploiting them exhaustively. Therefore, the town administration should carefully assess and find new revenue sources and exhaustively exploit the existing revenue sources by implementing revenue rules, regulations and procedures.

\section{Improve planning and implementing capacity}

Poor planning has an adverse effect on the town's achievement of development activities like assessment and collection of allowable town revenue. Hence, planning system should be improved in a way that can forecast future actions properly. Moreover, the implementing capacity must be developed through provision of appropriate and sustained training to the staff of the town administration to increase their commitment and fill skill gap.

\section{Establishing adequate data base systems}

As data obtained in the field work revealed, the town administration has not exercised an organized data base management. As a result, revenue planned and actually collected had shown large deviation from year to year. Therefore, by improving the data base management, the town administration should smooth the progress of its revenue collection hence promote revenue management.

\section{Raising Continuous awareness for taxpayers}

To reduce the number of illegal traders and non-registered taxpayers and increase revenue, one of the important tasks to be done is providing organized information to the taxpayers as to why the payer is charged. This enables the taxpayers to link the relationship between tax obligations and town service delivery. Taking this fact in to consideration, the town administration should design and implement awareness creation program for the residents of the town in general, taxpayers in particular.

\section{Institutionalizing standard accounting system that produces timely and reliable information}

One of the tools in public finance management to manage revenue is performance reporting in a timely and reliable manner. The accounting system used by the town is not fully computerized that it cannot provide up to date and clear financial information. Hence, improved accounting system should be designed and implemented so that comprehensive financial reports can be produced and used for decision making.

\section{Encouraging community participation in planning and resource collection}

There should be active participation of the residents in needs identification, planning and implementation process. This could help in promoting transparent and participatory decision making.

In Contrast, Halaba special town administration had not encouraged the participation of community in development activities of the town. Therefore, the town such as planning and increasing revenue collection plan administration should promote community participation during planning and implementation process through the use of full council meetings.

\section{A need for designing the reward system}


There should be an implementation of integrated performance management system in order to reward employees according to their performance in order to boost their commitment. this helps town administration capable of retaining competent staff as well as attracting new ones to fill vacant positions.

\section{Acknowledgment}

All praise is due to Allah under whose might all worlds are subdued and hearts acknowledge who allow me to finish this thesis and without his will I couldn't able to perform .Next,I am deeply indebted to express my appreciation and thankfulness to my dear advisor, Dr. Derege Terefe whose help, excellent advice, academic guidance, inspiring suggestions and supervisory encouragement continuously helped me throughout the time I spent on conducting the research and preparing this thesis to make it a better thesis which without his directives this study would not have to come an end and would not become tangible.

Great thanks also go to Ministry of women, youth and children affairs for providing this scholarship to HPR to empower women, which I have been one of the beneficiaries and to government of Ethiopia and its women. In addition, undoubtedly, my especial and deepest gratitude goes to my dear husband and family members their overall support. Including, my niece, my brothers Seadu Shifa and Nesiru Jemal for their material support.

I would also like to deeply extend my thanks to the employees of Halaba special Woreda Town administration and Inland revenue office for their cooperation and support particularly, to Mayor of the town, Kedir Koricho, for his support to provide all the necessary information I needed from his office and facilitating me other offices.

Again, my special gratitude goes to Halaba Special woreda president, Nuredin Hassen, for his financial support during my study, Finally, I would like to express my sincere thanks to my best friends and colleagues, Tirunesh Tarik and Belynesh Tadesse.

\section{Reference}

1. Aaron H, Slemrod, J (Ed) (2004). The crises in Tax Administration. Washington D.C .The brookinginstitution.

2. Alan Walter Steiss and Emeka O. Cyprian Nwagwu (2001).Financial planning and management in public Organizations. New York. BASEL.

3. Allen Schick (1999). Governance, regulation, and Finance Division A contemporary Approach to public Expenditure management.

4. Amanuel Kussia (2013). Development theories and strategies reader institute of public management and Development studies (IPMDS).

5. Anderson. J.E (2003). Public Financial. Houghton Miffine Company. New York

6. Andrews, M (2008) 'How Far Have Public Financial Management Reforms Come in Africa?'Faculty Research Working Paper. Cambridge, MA: Harvard Kennedy School. http://web.hks.harvard.edu/publications/getFile.aspx?Id=548. (accessed at december-9-2014).

7. Bacorreza, Gustavo, Jorge Martimez-vazques, and cristain Sepulveda (2012).Sub national revenue mobilization in Peru. International center for policy working paper 12.www.ids.ac.uk/local government htm.(Accessed at march 15-2015)

8. Bridi, A (2010).Tax challenges facing developing countries. New Delhi; University of Toronto.

9. Dancorry, P. (1997). Public Expenditure: Effective management and control. Great Britain, London.

10. Edson Mbedzi and Gondo T et al (2010). Fiscal management in Dangila Municipality, Ethiopia, performance and policy Implication.

11. ERCA (2008). Bank reconciliation, and revenue sharing between regional and federal government.

12. Explanatory Note (2002).Revenue management. Technical competency dictionary. 
13. Federation of Tax Administration(2003). Revenue management in revenue office.Sierka

14. Fiscal Affairs Department March 8, 2011. International Monetary Fund revenue mobilization in developing country.

15. Giugale. M.M. and Webb, S. B (2000). Achievements and challenges of fiscal decentralization, The World Bank, USA Washington D.C

16. Giunakis. and Mc Cue. (1999). Local Government Budgeting. Edward Elgar publishing inc.USA.

17. Graeme Chamberlin and Linda Yueh (2006,p358). Macroeconomics.

18. Graeme Chamberlin and Linda Yueh(2006, p358).Macroeconomist

19. Growth and Transformation Plan Document of Ethiopia (2003-2007).

20. Human resource management reader (2013). Human resource management course. Ethiopian Civil Service University.

21. Jan werner and David Nguyen-Thanh (2007). Municipal infrastructure Development in Ethiopia. Available at www.mof-go-tz/mofdoes/msemnji/pfm Rp\%20iv\%20strategy.pdf

22. John L. Mikesell (2007). Fiscal administration. Analysis and application for public sector.

23. JRA (2005).Challenges of public sector revenue management. African Development Bank. Available at:WWW.afdb.org/--/publications/1145499-EN.(Accessed 20/2/2015 at 4:pm)

24. Mahi Khallaf, AU researcher and, Carmen Malena, Director (2014); Public revenue reporting and monitoring. civic participatory governance program.

25. Mbility, A and Mutalemwa. D (2010). Informal sector taxation in Tanzania, TAKNET policy Brief series No.12 (online).Available at http;//.www.taknet.or.tz/topics/I NFORMATIONsectorTAXATIONTANZANIA_12,PDF,Accessed on $25^{\text {th }}$ may,2015.

26. Ministry Of Finance and Economic Development (2009). Lay person guide to the public budget process at regional level.

27. Mirjam (1995). Local Economic development and urban management. Experience of porto Alero Brazil,

28. Mukhtar Musse Ahmed (2014). Challenges of tax assessment and collection in Ethiopian Somali regional state; Institute of tax and customs administration. Department of public financial management.

29. Mwaqwo, Financial planning and management in public organization. Emekao. cyprian Graduate school documentation658.15sTE

30. Ndemanyisho (2014) .In Tanzania revenue collection. International journal of Education and research vol.2No.8 August 2014.Available Email agysiya@yahoo.co.uk.Accsesed .(accessed 22/3/2015)

31. New thinking .Available at (www.cangemini.com/---/tl-Tax-Rev-management).accessed at April $\underline{5-2015}$

32. Nice, D. (2002). Public Budgeting, Wadsworth Group, USA, Canada

33. Oracle (2011). Oracle revenue management for local government. Oracle and Java. Available at www.Oracle com/goto/tax. Accessed at March 10-2015.

34. Patrick Adu Sarfo and Richard Baoh (2013) Challenges of revenue management in developing countries. Institute for development studies (IDS) and University of Cape Coast, Ghana

35. Patrick Adusarfu and Richard baoh (2013). Maintain Kunasi senior High school Ghana institute for development studies (IDS), university of cope coust, Ghana

36. Rahel Jigi (2012). Raising revenue for management of Wetlands. Institute of Tax and customs Administration.

37. SAP (2008).Tax and Revenue management for public sector. Global Alliance Executives. Available at www.capgemini.com/public(.Accessed at April 10-2015)

38. Scutaru, C., (2009), ('Marketing for public sector"), In Calitatea Vieii, 1-2: 63.

39. SOAS, University of London. Revised 2003, corrections 2007, revised 2010, corrections 2011, 2012. C Centre for Financial and Management Studies. 
40. Steven A. Finkler (2005). Financial management for public health and not for profit organization.and Francis and Taylor (2006). Public financial management .public administration and public policy.

41. Swanson R. A, and Holton, E.F iii Eds (2001).Foundation of human resource development. A Francisco Berrett_Koehler.

42. Tanzi, V (2000). Inflationary expectations, economic activity, taxes and interest rates. The American Economic Review,36,12621

43. The constitution of the Federal Democratic Republic of Ethiopia. $1^{\text {st }}$ year No.1ADDIS ABABA$21^{\text {st August, } 1995 .}$

44. The working procedure and members' code of conduct; the House of peoples' representatives of the FDRE of 2005.

45. V.K. Bhalla(2008,p598)Management of financial services. $4^{\text {th Revised and }}$ Enlarged Edition

46. Xiao Hu Wang (2006). Financial management in the public sector. New York Landon.

47. Yasin Nur (2012). Problem of tax revenue administration in Somali land Harergeisa Municipality. ECSU institute of tax and customs Administration.

48. Yousuf Mohamed Adem; The main challenges facing the Inland revenue Bureau in Administrating direct and indirect taxes in Harergeisa city Somali land-institute of tax and customs Administration. 


\section{Factors affecting public sector revenue management in the case of Halaba special woreda town administration (SNNPR)}

\section{Institute of public development studies}

This questionnaire does not have any impact on institution's/company's image, good will, or any other side, and provided information is highly confidential. It is designed for the purpose of my thesis paper on assessing factors that affect public sector revenue management in the case of Halaba special woreda Town Administration, as a part of the fulfillment for the award of master's in public management at the Ethiopian Civil service University, I hereby respectfully ask in advance for your help. Read carefully each question clearly without hesitation and try to answer according to your knowledge, experience and belief. Dear respondents I would like to express my deepest appreciation for your generous time, honest and prompt responses.

\section{Part one}

1 Back Ground Information

1.1 Age:- a) $20-30$ b) $31 \_40 \quad 41 \_50>51$

1.2 Sex:- Male Female
1.3 Educational Statues:-
a) certificate
b) diploma
c) degree
d) masters
1.4 Work Experience
a) 1-3 year b) 4-6
c) $7-10$
d) $>10$

\section{Part Two}

Notice Please put tick mark in the box in front of your response, agree $=3$, strongly agree $=4$, disagree $=2$, strongly dis agree $=1$

1) What is the major sources revenue of the town administration?
a) Value added tax
b) Property tax
c) Hawkers and traders tax
d) Business license tax
e) Government grants
f) Others

2) Accounting for revenue collected is done in proper government accounting system.
a) Agree
b) strongly agree
c) disagree
d) strongly disagree

3) If you agree or strongly agree question no 2, which types of device do you use for registering and identifying taxpayers?

a) Manual 
b) Automation system

c) Both of them

4) Which mechanism do you apply for the collection of revenue in the town Administration?

a) Manual

b) Automation

c) Both of them

5) Revenue collection is carried out with legal voucher.

a) agree b) strongly agree c) dis agree d)strongly disagree

6) Revenue is collected through clear rules, regulations and procedures

a) agree b) strongly agree c) disagree d) strongly disagree

7) Complaints are solved timely.

a) agree b) strongly agree c) disagree d) strongly disagree

8) Public attitude towards public revenue is positive

a) agree b) strongly agree c)disagree d)strongly disagree

9) The salary paid for revenue collection officers are sufficient.

a) agree b) strongly agree c) dis agree d) strongly disagree

11) Revenue bases are assessed well.

A) Agree b) strongly agree c) disagree d) strongly disagree

Please specify if you have any additional comments

Questions related to revenue planning

12) Revenue is determined based on actual need
A) Agree
b) strongly agree
c) disagree
d) strongly disagree

13) Tax payers register their actual revenue amount
A) Agree
b) strongly agree
c) disagree
d) strongly disagree

14) The proper forecasting method is employed for estimating revenue.
A) Agree
b) strongly agree
c) disagree
d) strongly disagree

15) If you agree or strongly agree, what are the forecasting mechanisms adopted in your office?
a) Assumption criteria
b) systematic evidence
c) fixed amount projection

Please specify if you have any

Questions related to revenue management mechanism

16) Qualified employee is hired for revenue collection.
a) Agree
b)strongly agree
c)disagree
d) strongly agree

17) There are different types of reward system in order to motivate employees based on their needs
a) Agree
b) strongly agree
c)disagree
d) strongly disagree

18) If you agree or strongly agree on Q17, to what extent you agree the reward system designed will promote revenue?
a) Excellent
b) very good
c) good
d) bad 
What do you recommend to improve revenue management in the town Administration?

Thank you very much for you support

Factors affecting public sector revenue management in the case of Halaba special woreda town administration (SNNPR)

\section{Institute of public development studies}

This questionnaire does not have any impact on institution's/company's image, good will, or any other side, and provided information is highly confidential. It is designed for the purpose of my thesis paper on assessing factors that affect public sector revenue management in the case of Halaba special woreda Town Administration, as a part of the fulfillment for the award of master's Degree in public management at the Ethiopian Civil service University, I hereby respectfully ask in advance for your help. Read carefully each question clearly without hesitation and try to answer according to your knowledge, experience and belief. Dear respondents I would like to express my deepest appreciation for your generous time, honest and prompt responses.

Questions for Tax payers

Notice; please thick one among the given alternatives. Agree $=3$, strongly agree $=4$, disagree $=2$, strongly dis agree $=1$

\section{Part 1-Personal information}
Gender
a) male
b) female

Education level

b) secondary

c) certificate

d) diploma

e) degree and above

\section{Part two}

1) To what extent youagree that the government is trust worthy to collect revenue from its citizens?
a) Agree
b) strongly agree
c) disagree
d) strongly disagree

2) To what extent you agree that the taxes you pay are fairly assessed?
a) Agree
b) strongly agree
c) disagree
d) strongly disagree

3) If no, what do you think is the reason behind the unfairassessment? Please specify if any

4) To what extent you agree the authority properly identifies and register all tax payers of the town?
a) Agree
b)strongly agree
c)disagree
d) strongly disagree

5) How do you come to the tax net?
a) By your own initiative b)
b) by the Authority's advertisement
c) by enforcement

6) Which types of tax are you levied?
a) Property tax
b) Hawkers and traders tax
c) ownership transfers
d)specify if any other

7) When do you pay tax?
a) on time
b) with a penalty 
10) Do you think that there is sufficient and committed man power in the office?

a) Yes b)No

11) Do you face any problem when you pay tax?
a) Yes
b) No

10) If the answer for Q9is yes, what kind of problems do you face? Please specify

12) Do you believe that the illegal traders andnon-registered taxpayers have an impact on your attitude towards tax?
a) yes
b) No

13) If the answer Q11 is yes, How? please explain

14) What do you suggest the overall improvement of revenue collection of the town administration? Pease explain briefly

if

you

have

any

idea

Thank you very much for your support 


\section{Factors affecting public sector revenue management in the case of Halaba special woreda town administration (SNNPR)}

\section{Institute of public development studies}

This questionnaire does not have any impact on institution's/company's image, good will, or any other side, and provided information is highly confidential. It is designed for the purpose of my thesis paper on assessing factors that affect public sector revenue management in the case of Halaba special woreda Town Administration, as a part of the fulfillment for the award of master's Degree in public management at the Ethiopian Civil service University, I hereby respectfully ask in advance for your help. Read carefully each question clearly without hesitation and try to answer according to your knowledge, experience and belief. Dear respondents I would like to express my deepest appreciation for your generous time, honest and prompt responses.

Interview questions for Focus group discussion and higher officials

1) What are the existing and potential sources of revenue for the town administration?

2) How were the trends of tax revenue for last three years?

3) What are the factors that affect revenue management in the town Administration?

4) What are the methods and procedures employed for assessing and collecting revenue?

5) Do you think the salary paid for revenue collection officers are sufficient?

6) Do you think Tax imposed on taxpayers is fair?

7) Do you think revenue base is addressed well?

8) Do you think there is fair treatment of taxpayers in the town administration?

9) Do you think revenue is collected based on Governmentrules and regulations?

10) What are the core control mechanisms and procedures you apply for revenue management?

11) What management mechanism you employ to improve revenue management efficiency?

12) To what extent the management mechanisms contributed to revenue management efficiency?

13) What do you recommend to improve revenue management in the town administration?

Thank you very much for your support. 